\title{
The Use of Underground Metro Stations and Tunnels as Protective Structures in Case of Nuclear Emergencies
}

\author{
Mohamed Farahat \\ Department of Siting and Environment, Egyptian Nuclear and Radiological Regulatory Authority, Cairo 11787, Egypt
}

\begin{abstract}
This paper discusses the use of Underground Metro stations and tunnels as protective structures in case of nuclear emergencies. Six lines are taken as a case study to investigate the use of their underground stations and tunnels. The research explains the structural design of Underground Metro and the necessary needs for hidden people inside Underground Metro used as shelters. The research investigates the calculations of the number of hidden persons inside Underground Metro used as shelters. A field study has been conducted to an Underground Metro station to determine the peaceful use and the emergency use of all basements of the station. Also, the field study aims to determine the existing spaces and the needed spaces of the Underground Metro station to dual—used as a nuclear shelter. Three Underground Metro stations have been selected and a field study has been conducted to determine the usages of these basements, the planning, general and design features for each one of them, and whether they can be used as protective structures for citizens in emergencies. These basements were compared for their protective factors. Also, their capacities for sheltering were calculated.
\end{abstract}

Key words: Underground Metro, stations and tunnels, protective structures, nuclear shelters, nuclear emergencies.

\section{Introduction}

The nuclear bomb produces fallout (radioactive particles) drop down to the ground near the explosion place. The fallout could be also carried by wind for hundreds of miles, and later drop down to the ground, or settle on buildings and trees as sand particles [1]. These fallout particles produce ionizing radiation like $\mathrm{x}$-rays, which cannot be seen or felt. This radiation is dangerous. The exposure to heavy doses of this radiation causes sickness, and might well cause death [2]. The fallout dust remains radioactive for some days after the explosion, and in certain circumstances, may still be dangerous after several weeks. Nuclear shelters are, therefore, necessary for protection against these dangerous effects of the nuclear weapons [3].

The practice of building nuclear shelters is wide-spread in many countries such as USA, UK, Sweden, Norway, Finland, Switzerland, Canada, China and Russia. Arab citizens are afraid from the nuclear weapons and their fallout radiation.

Corresponding author: Mohamed Farahat, Ph.D., research field: architecture.
Underground Metro stations and tunnels as public buildings are special in the fact that most of their spaces are designed for receiving congregations of people and trains. These stations and tunnels can receive masses of people for a period of time. So why not make use of this property by designing them as protective structures in case of national emergencies? Most of the developed countries have used their Underground Metro stations and tunnels as protective structures in case of emergencies, after providing them with equipment and necessary supplies, to protect their citizens from dangers [4].

\section{The Dual-Use of Railway Tunnels as Public Nuclear Shelters}

Those tube tunnels (Fig. 1) were used during the early 1940s to protect the Londoners from Hitler's high explosive bombs [5]. Now, their entrances are hidden from the public eye by bland steel doors. Trains do not run through them. Rows of rusting iron bunk beds are still in place. Those shelters are $30 \mathrm{~m}$ to $45 \mathrm{~m}$ down and they consist of two parallel station 


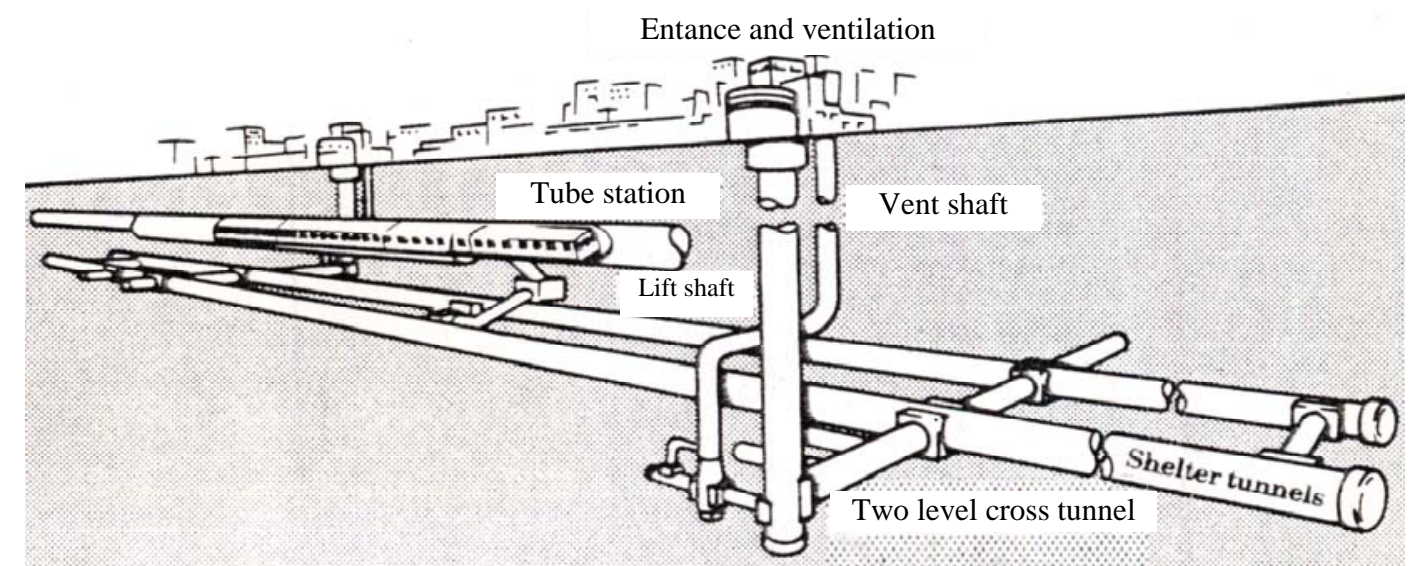

Fig. 1 London reinforced concrete railway tunnels were dual-used as public nuclear shelters during the Second World War [5].

tunnels of $427 \mathrm{~m}$ long and $5 \mathrm{~m}$ in diameter lined with reinforced concrete segmental rings [6].

These tunnels are joined by interconnecting passages at either end, and divided into an upper and lower floor by pre-cast concrete planks supported on mild steel beams and columns. Each shelter was designed to accommodate 8,000 people and toilets. Much of the original equipment, in addition to the beds, is still in place. Foul air was extracted through ducts in the floors and ceilings and forced to the surface through the exhaust shafts at each end of the complex. Fresh air normally entered the tunnels via the staircases and shafts, but the system was reversible. Each shelter was originally equipped with four fans giving a total output of around $1,100 \mathrm{~m}^{3} /$ minute and driven by 600 volt motors [7].

The public reach these shelters via steps from the tube station upstairs, but these accesses were blocked off long ago. On the surface, it is still possible to see the pill box like structures at the top of the lift shafts. With their steel doors, they resemble electricity substations. Mains of water were piped down below but draining the waste proved more troublesome as there could be no gravity connection to the main sewer. Eight lavatory passages off the main tunnels contain urinals and chemical toilets. Contents of the filled toilets had to be emptied into a wooden lidded steel hopper at the end of the lavatory. Wire mesh screens kept debris which would have blocked the drainage system [8]. The hoppers, urinals and sink wastes from the canteens are connected by a series of pipes to an ingenious compressed air ejector system driven by a motor which pushed the contents up through a $150 \mathrm{~mm}$ rising main to the sewer in the street [9].

\section{Greater Cairo Tunnel Metro Lines}

As the biggest and most densely populated city in Africa and the Arab World, the case for a metro in Greater Cairo was strong. Cairo Tunnel Metro is the first rapid transit system in Greater Cairo, Egypt and the first of only two full-fledged metro systems in Africa and only four in the Arab world. The underground great Cairo Metro network is designed to link the governorates of Cairo, Qalyoubia and Giza (Fig. 2). As of 2014, the Cairo Tunnel Metro has 61 stations, of which 3 transfer stations with a total length of $77.9 \mathrm{~km}$ long. The system consists of three operational lines numbered from 1 to 3. Cairo Metro has the first tunnel under the Nile river in history, as the Line 2 extends under the river [10].

\subsection{First Underground Cairo Metro Line}

The construction of Line 1 started in 1982. The first section was opened in 1987. Line 1 is the oldest line of the Cairo Metro, with its first 29 kilometer segment from Helwan to Ramsis square. The line was completed in 1989 connecting Helwan with El Marg 


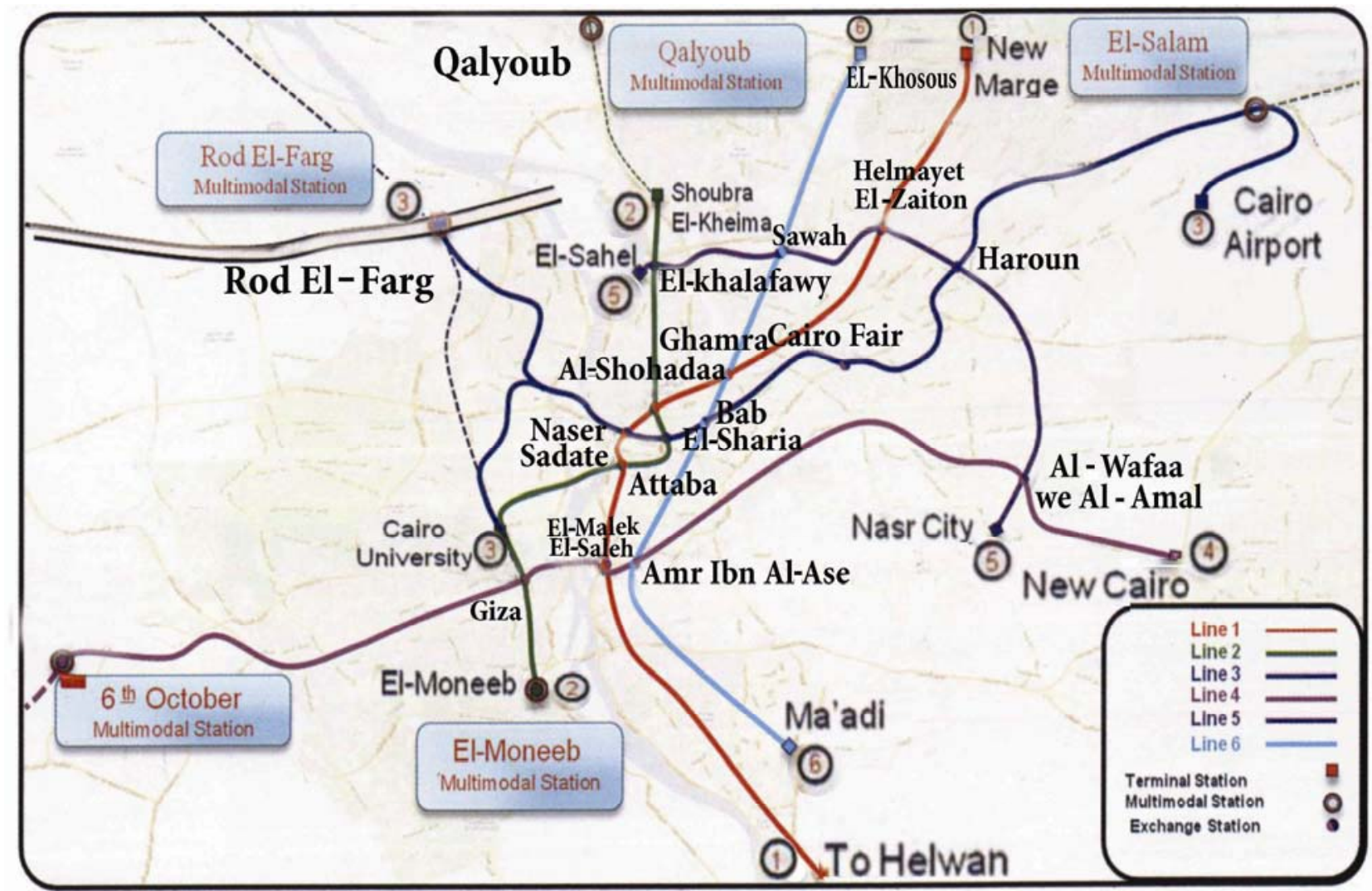

Fig. 2 Greater Cairo Metro network to be executed up to 2022 [11].

and consisting of 33 stations with a total length of 43 $\mathrm{km}$. The line witnessed few developments since 1989, New El Marg station was added in 1999 to the northern end of the line. Helwan University station was built between Wadi Houf and Ain Helwan stations. This line extends from Helwan to New EL-Marg. Only 4.2 $\mathrm{km}$ are in an underground tunnel that extending from Mobarak station to Zaghlol station. The line is 44.3 $\mathrm{km}$ long and serves 35 stations. Line 1 had a train driving simulator [12]. Its internal width is $8.70 \mathrm{~m}$ and its internal height is $6 \mathrm{~m}$. Its structure is reinforced concrete. This line is equipped with lighting and power stations. Also, the underground part is equipped with an air conditioning system.

The first line tunnel was provided with adequate protection to avoid the collapse of the soil and taking into account the water table. The soil (3 m thickness) below the bottom of the tunnel was injected to strengthen the soil and prevent groundwater from leaking into the tunnel [13]. There are five underground stations in Line 1 serve densely populated areas. The distance between the station and the other is not exceeding 1,200 m [14]. Cairo's Metro network was greatly expanded in the mid-1990s with the building of Line 2, from Shoubra El Kheima to Cairo University, with an extension to Giza. The construction of the line was finished in 2000, which later extended to El Mounib. Line 2 is the second line of the Cairo Metro. The line is $21.6 \mathrm{~km}$ long, of which $13 \mathrm{~km}$ is in tunnels. It serves 20 stations. It is mostly in bored tunnel. Line 2 uses the third rail electrification system instead of the overhead line used in the first line. The communication extension for Line 2 was provided in 2005. The Line 2 has a simulator installed in Shubra since 2002 [10].

\subsection{Second Underground Cairo Metro Line}

It extends beneath both branches of the Nile (Fig. 3). Its depth may reach 10.5 meters beneath the river bed. The tunnel body is formed from reinforced concrete. 


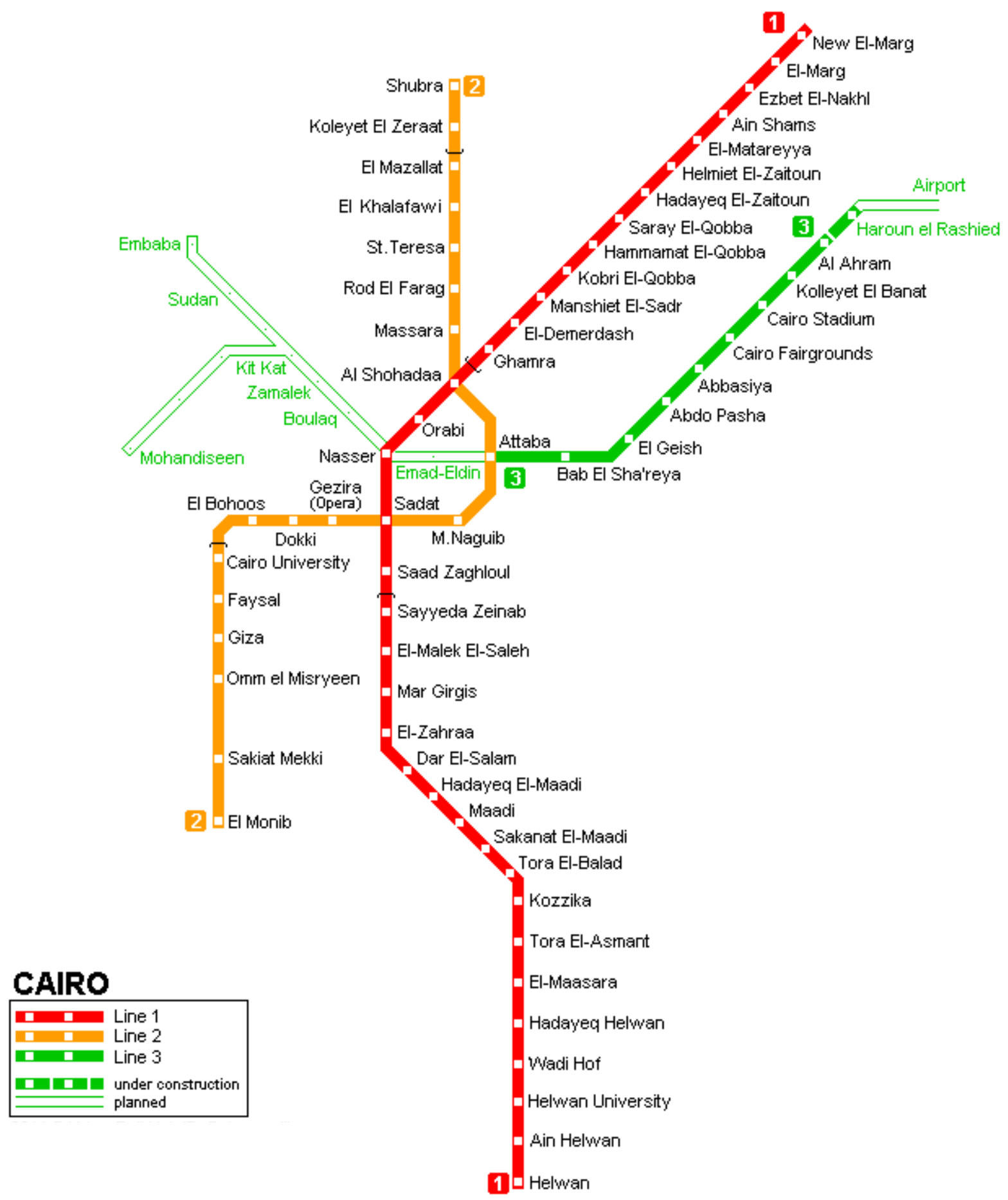

Fig. 3 Greater Cairo Tunnel Metro [13].

A modern drilling machine has been used to carry out its entire construction. The outer diameter of this tunnel is $9.11 \mathrm{~m}$ and its internal diameter is $8.35 \mathrm{~m}$. This line links the populated district places such as Shobra, down town and Giza. Also both banks of the
Nile are linked for the first time (Fig. 4). It also links railway stations with Underground Metro stations, thus facilitating public transportation. Each metro station has a number of entrances, commensurate with its location and the potential number of the passengers. 


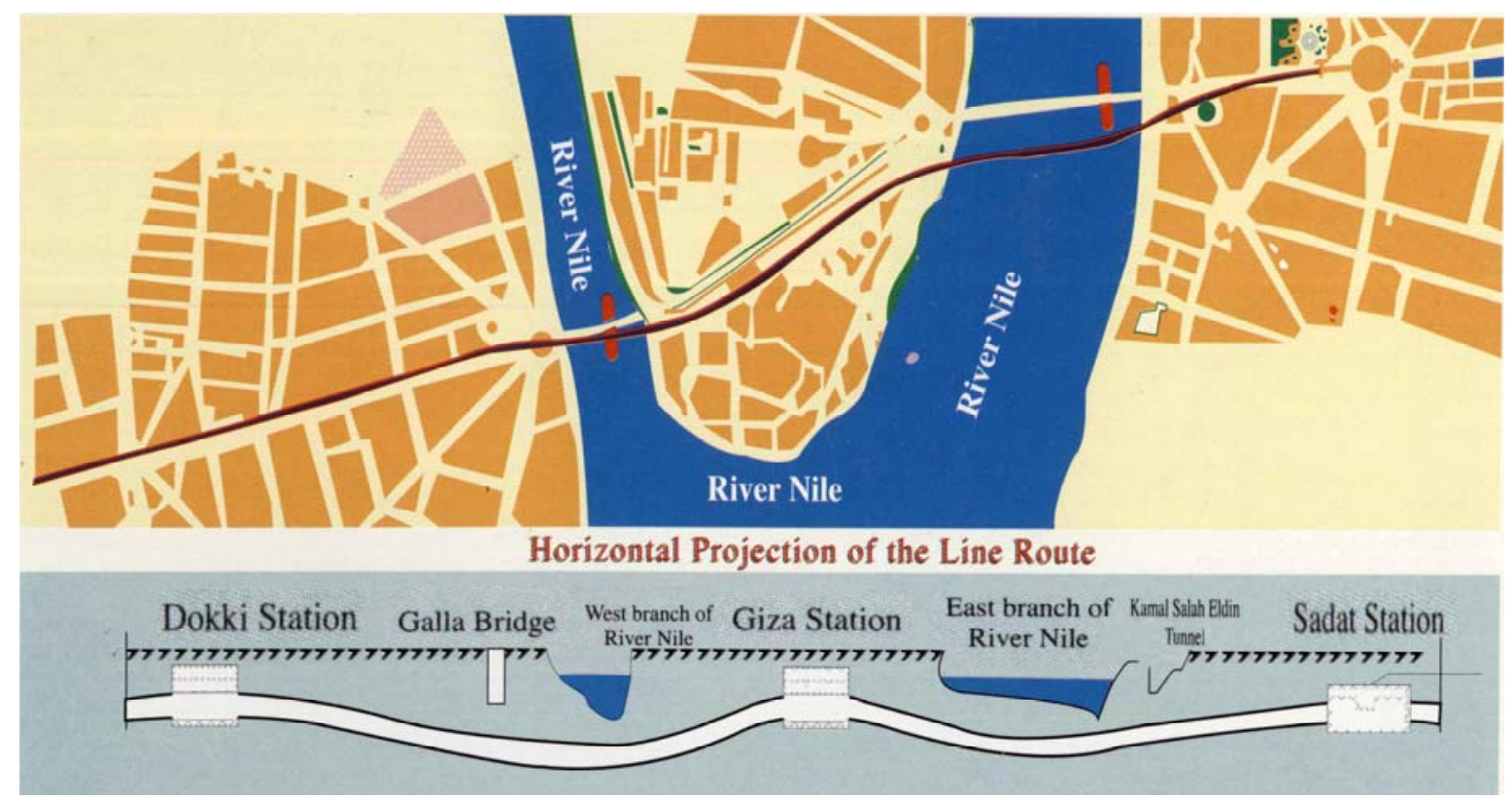

Fig. 4 Greater Cairo Tunnel Metro (Line 2) passing under the two branches of the Nile river for the first time in 1997 [11].

This tunnel is equipped with lifts, escalators and a ventilation system that is efficient and convenient for all stations and the tunnel track. This tunnel is also provided with an electric feeding power, an automatic fire network and a modern communication system. It also links big squares such as Shobra, Ramses and Tahrir squares. This line contains 12 underground stations. Its depth ranges from $12 \mathrm{~m}$ to $17 \mathrm{~m}$ under the earth's surface [12].

The second line contains 3 underground stations; each one consists of 2 floors. Also, the second line contains 9 underground stations; each one consists of 3 floors. The average distance between the second line stations is about $1,000 \mathrm{~m}$. The upper floor of the station (consisting of three floors) is dedicated to tickets galleries and service of citizens. The middle floor is dedicated to electro-mechanical equipment and operation crew. The lower floor is dedicated to the platforms and the movement of trains.

Passengers are going from one floor to another by electric escalators. There are elevators to carry the disabled persons from the street level to the platforms. There is a ventilation system for underground stations and tunnels. This system consists of 6 air treatment and air conditioning units. There are 30 units for the dewatering of the tunnel. The interior design of the stations was done by professors of architecture and fine arts in Egypt. Each station is an independent facility. It has its own refrigeration units and power supply [12].

\subsection{Third Underground Cairo Metro Line}

Line 3 presently operates from Attaba to Ahram (Heliopolis), with construction under way for the remaining line to the northwest of Greater Cairo. Eventually, it would link Cairo international airport all the way to Cairo University and Imbaba (Fig. 5). The line will cross under the two branches of the river Nile, as does Line 2. The total length of the line will be approximately $50 \mathrm{~km}$, most of which in bored tunnel, and will be implemented in four phases [10].

Phase 1 from Attaba Station to Abbassia Station opened on 2012, with five stations and a total length of $4.3 \mathrm{~km}$. Phase 2 to Al Ahram Station opened on 2014, with four additional stations and an added length of $7.7 \mathrm{~km}$, for a total length of $12.0 \mathrm{~km}$ [10].

Line 3 extends from Cairo airport to Imbaba, passing by Heliopois, Nasr city, Abbassia, Al-Geish street up to Attaba. This line will run crossing both Nile branches to Imbaba, Giza governorate. This line 


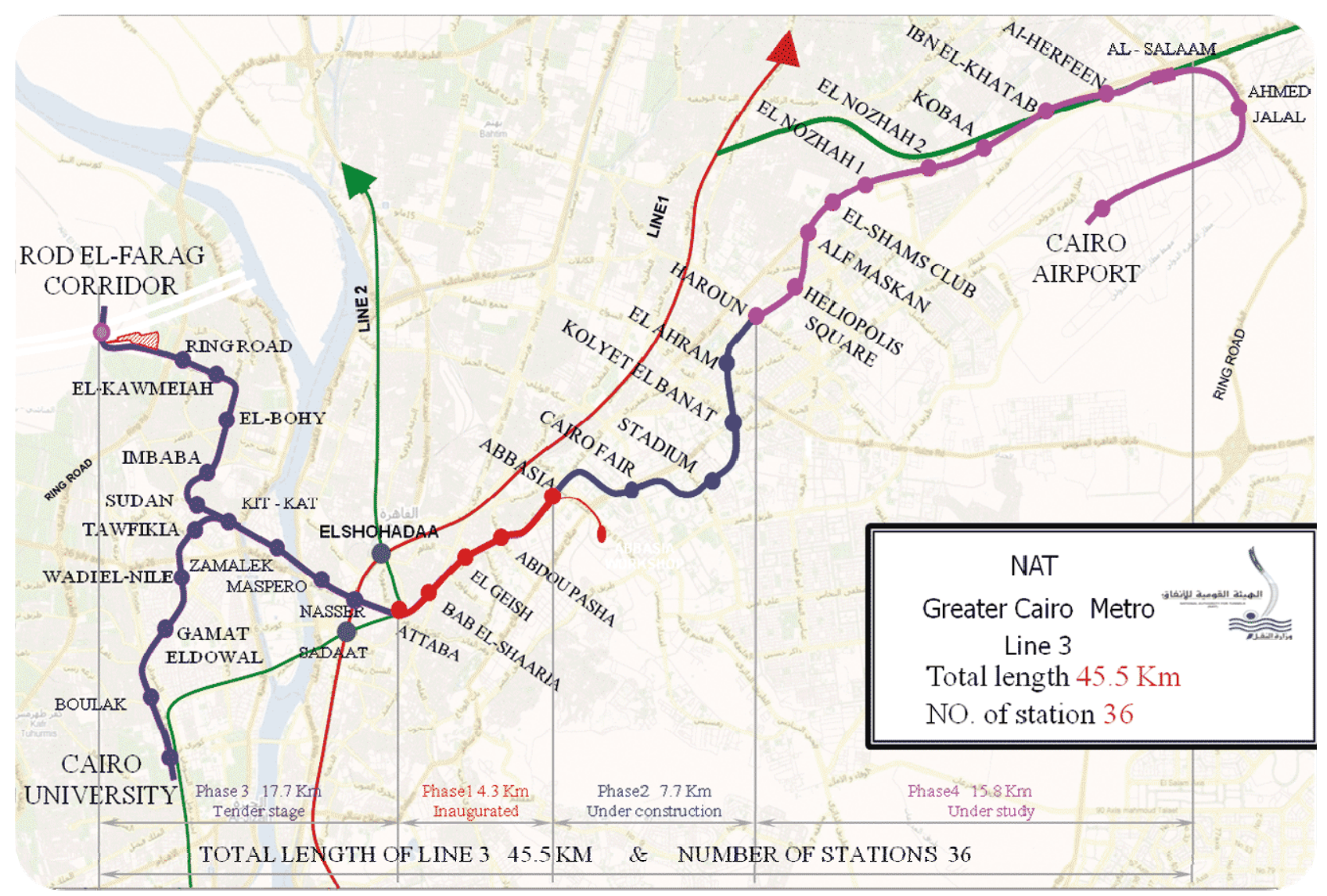

Fig. 5 Greater Cairo Tunnel Metro (Line 3) [11].3.4 Long Term Plans of Cairo Metro (Future Lines).

will require advanced technology as drilling will reach $35 \mathrm{~m}$ from the ground surface - ten meters deeper than the second line [10].

The first part of phase 3 of this line which starts at Ataba Station and ends at Kit Kat Station entered the construction phase in 2014. The construction fourth phase of this line (from Haron Station to Nadi El Shams Station) started in 2015. The previous two sections are expected to be completed by 2019. These three metro lines served by other projects which provide them with electrical power requirements, control operations and communication [10].

A transportation study of the Greater Cairo region was completed in 1999. It recommended the implementation of a six line system consisting of lines 1-3 (existing), and Lines 4-6. The completed metro network would be capable of serving most of the densely populated areas in the Greater Cairo region, which was much in need of a comprehensive mass transit system.

The plans include interchange stations between the six metro lines and would also provide interchange facilities with existing main railway stations, the airport and bus stations. The six planned metro lines aim to meet the transportation demands of the greater Cairo area up to the year 2022 [10].

\subsection{Fourth Underground Cairo Metro Line}

Line 4 is still under study. It is planned to run from Haram district reaching the New Cairo district connecting greater Cairo from west to east crossing the two branches of the Nile river with total length of $24 \mathrm{~km}$ (Fig. 6). Line 4 is expected to be fully operational by 2020 [10].

\subsection{Fifth Underground Cairo Metro Line}

Line 5 would be half-circular line connecting Lines 1-4, running from Nasr city to port Said street and 


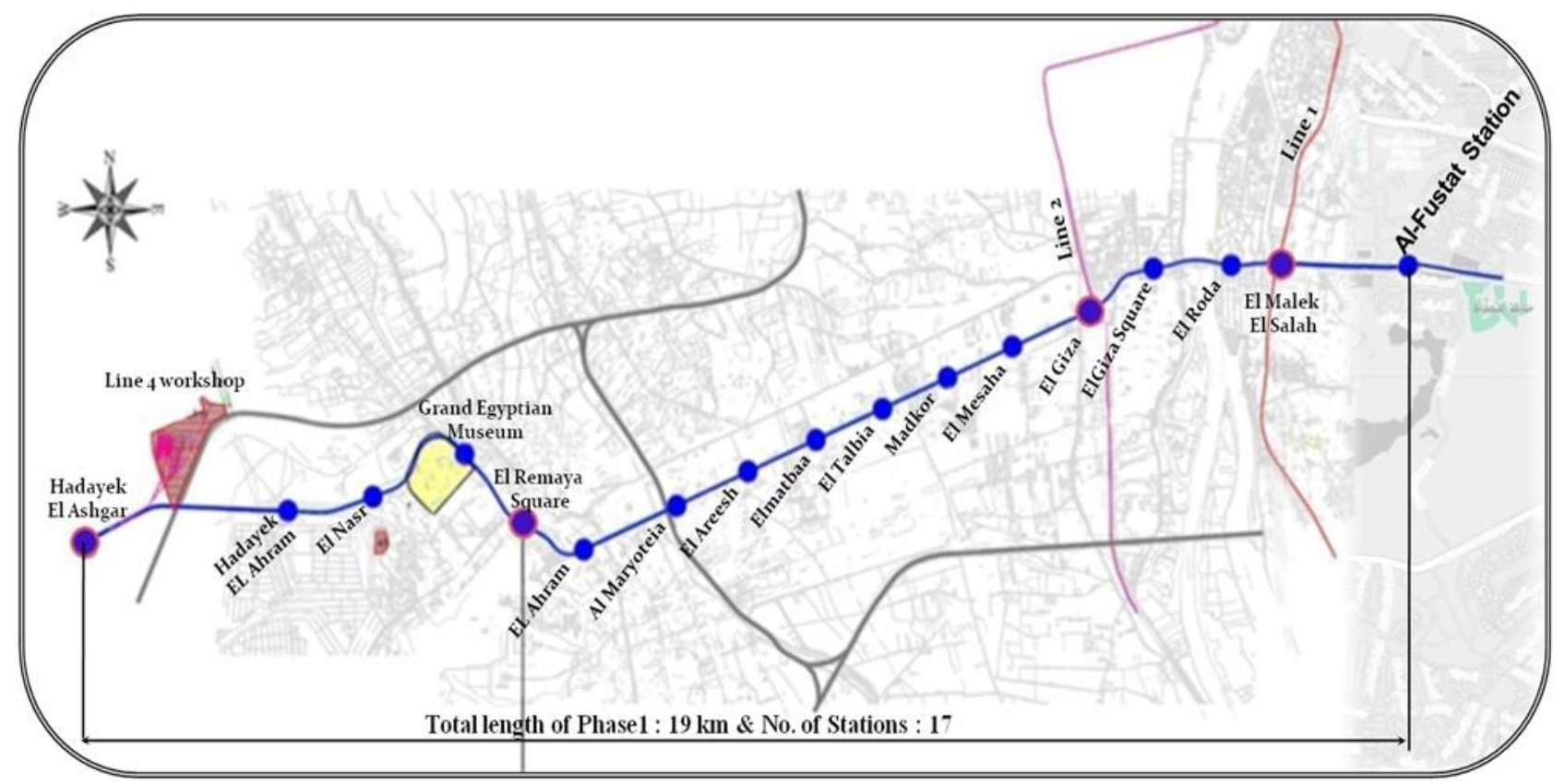

Fig. 6 Greater Cairo Tunnel Metro (Line 4) [11].

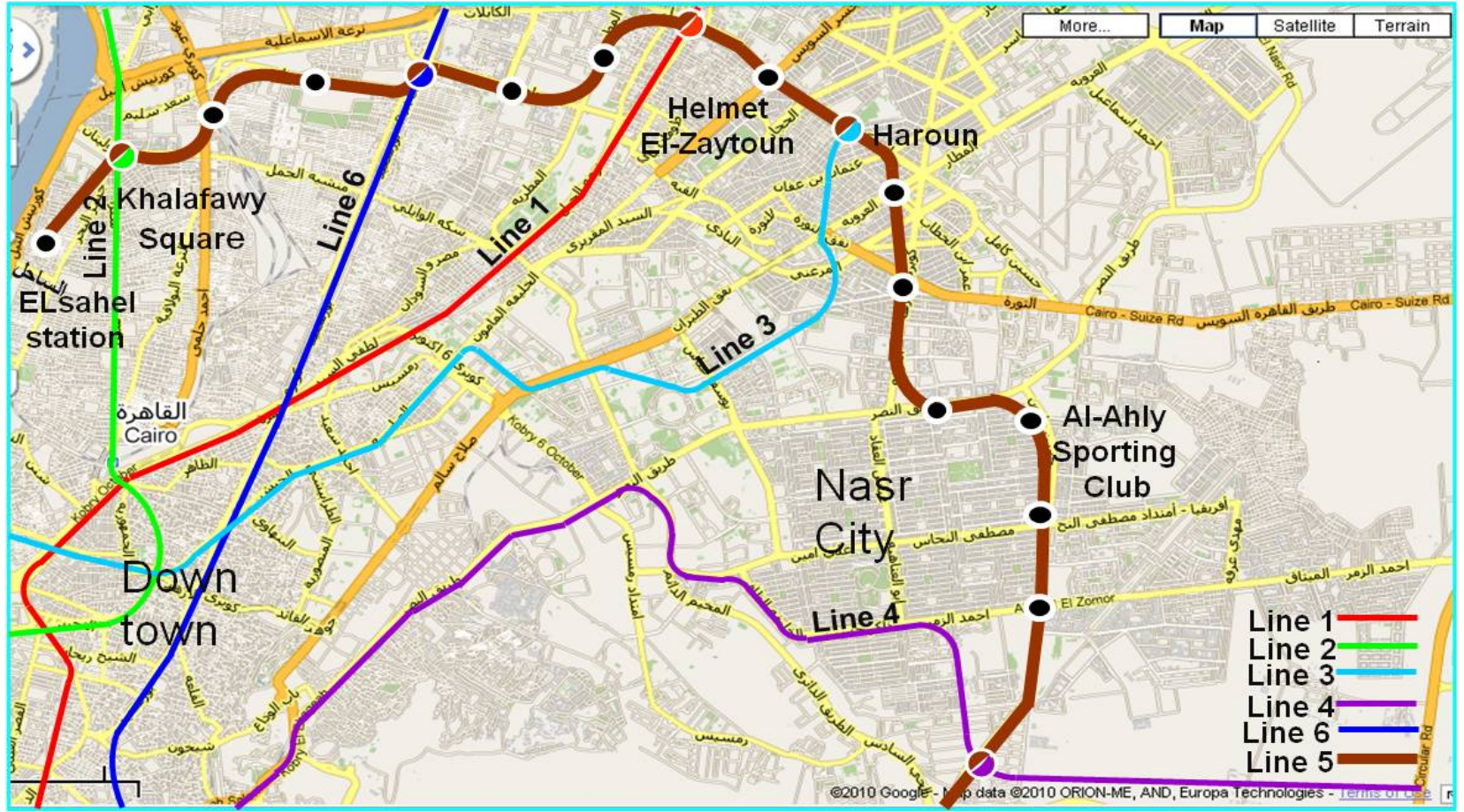

Fig. 7 Greater Cairo Tunnel Metro (Line 5) [11].

Shubra El Kheima (Fig. 7). It would have a length of $20 \mathrm{~km}$, entirely within bored tunnels [10].

\subsection{Sixth Underground Cairo Metro Line}

Line 6 will run from Shubra in the north until the heart of Maadi and Helwan districts in the south (Fig.
8). It will run from Ataba station (Interchange with both Line 2 and Line 3) through El Kalaa street in bored tunnels to Salah Eldin Citadel station (interchange with Line 4) and moving on from there to both districts via bored tunnels. This line has a length of $19 \mathrm{~km}$ [10]. 


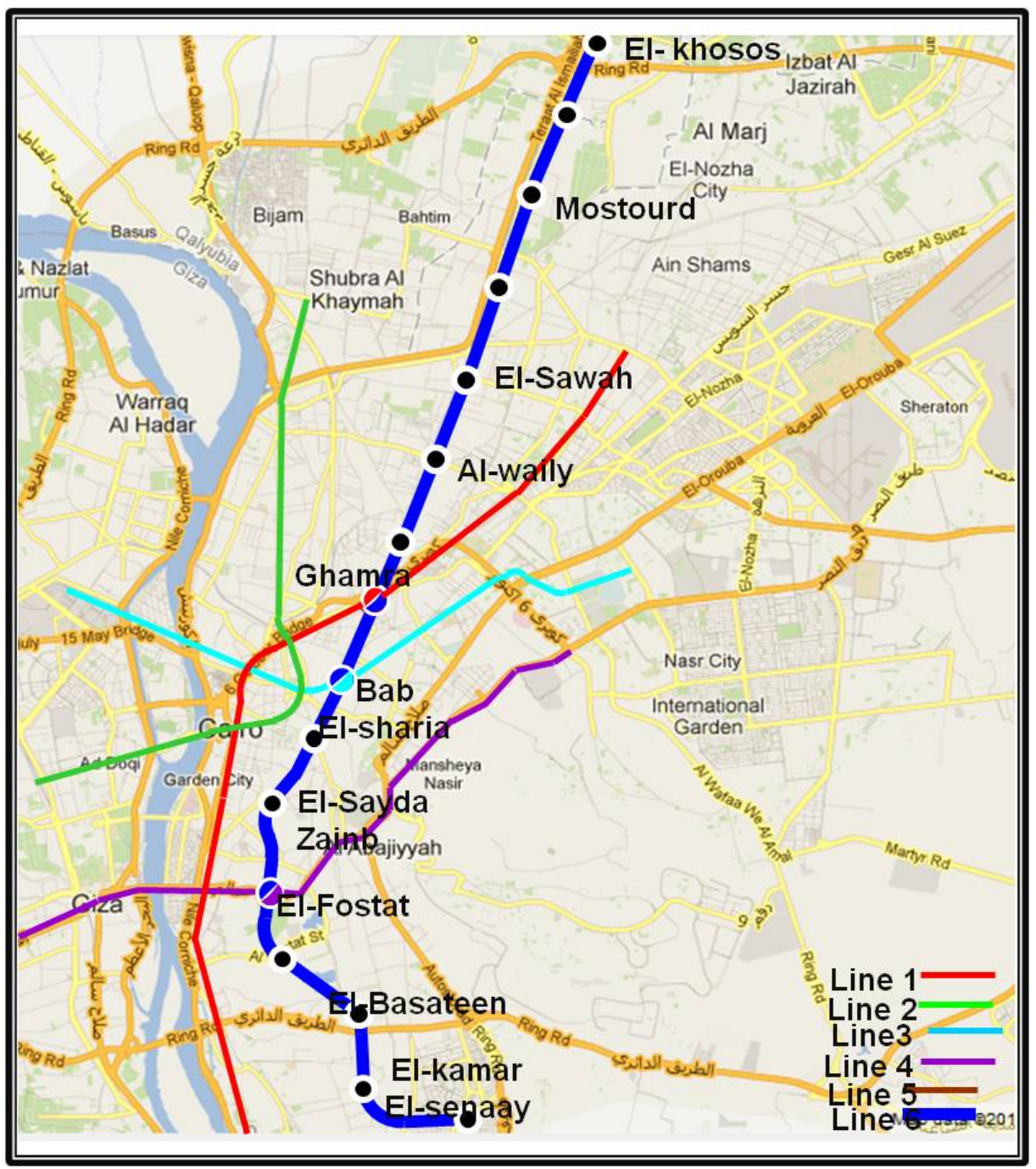

Fig. 8 Greater Cairo Tunnel Metro (Line 6) [11].

4. Analytical Study of Underground Cairo Metro Stations and Tunnels Which Can be Dual-Used as Nuclear Shelters

\subsection{General Concept}

The stations and tunnels are easily converted to public shelters in a relatively short time because they are equipped with some necessary mechanical and electrical installations [14]. The operation of the three lines is controlled automatically by the main central control building located in Ramses square. It can total control over the movement of trains and immediately suspend it if necessary and prevent it from entering the tunnel at the time of attack [15]. There are teams of police to protect the security of the metro stations and citizens. They are in direct contact with the control rooms and administration. There is an administrative staff to operate and maintain the metro composed of engineers and technicians [14].

These tunnels and underground stations can be dual-used as public shelters to protect citizens from conventional, nuclear, chemical and biological weapons. The use of these stations and tunnels will provide protection from:

(1) Pressure and fragments resulting from the explosion of bombs;

(2) Ruins of nearby buildings, after its collapse;

(3) Natural disasters, chemical factories accidents, 
leakage of toxic gases, floods or leakage of nuclear radiations from the reactors.

These stations and tunnels contain very large spaces which can be used as shelters to accommodate large numbers of citizens. Fortunately, they are located underground crowded squares such as Ramses square, Tahrir squar, etc. and near densely populated vital neighborhoods in the capital, making it easier to access quickly in cases of disasters and wars. Their Protective Factors (PF) are very large because they are entirely located underground. Therefore, these facilities are considered more appropriate to use as public shelters, offer protection against nuclear weapons effects. They must be provided with necessary requirements and equipment.

\subsection{Structural Design of Underground Cairo Metro} Stations and Tunnels Used as Nuclear Shelters

They are protected with a thick layer of soil. Their walls consist of reinforced concrete. The structural design of the stations and tunnels is very good. It has a major impact on reducing the impact of the blast and fallout radiations. The walls of the first line tunnel are precast reinforced concrete walls (45 cm thickness) [16]. The first line tunnels are rectangular shape while the second and the third line tunnels are cylindrical shape. This type of construction is more stable than traditional construction systems (beams and columns). Also, it is more efficient in its resistance against the external forces than traditional construction systems. The aerodynamic and curved surfaces reduce the intensity of reflected pressure. The stations and tunnels are located at great depths from the ground surface. They can protect the citizens from nuclear radiations.

\subsection{Necessary Needs for Hidden People inside} Underground Cairo Metro Stations and Tunnels Used as Nuclear Shelters

To use these stations and tunnels as nuclear shelters, they must be provided with the necessary humanitarian needs of the occupants in order to stay within the required period without suffering [17].

\section{(1) Air ventilation and filtration}

The stations and tunnels have been provided with 14 ventilation stations. There are three air cooling stations to adjust the temperature inside the tunnels at 20-28 ${ }^{\circ} \mathrm{C}$. The stations and tunnels are characterized by a high level of ventilation and a constant internal temperature. The ventilation stations can operate efficiently for a period of time not less than two hours after power failure. The floors of the underground stations and tunnels are ventilated by air conditioning systems. Moisture is appropriate. The concentration of carbon dioxide in air does not exceed $1 \%$ of air volume. The air does not include any rate of carbon monoxide, and there is no offensive smells. All these factors make underground stations and tunnels suitable for hiding. However, there is a need for fixing air filters to clarify the air from the entrance of radiating particles and fallout.

Any device heavier than $15 \mathrm{~kg}$ should be protected of shocks resulting from explosions by isolating it from the skeleton. The rest of the devices and equipment must be provided with a rubber layer of a thickness not less than $5 \mathrm{~mm}$. These underground stations and tunnels equipped with mechanical systems include ventilation and air conditioning systems that allow the survival for the hidden people during the emergency period. The air withdrawn into these facilities should be filtered with high efficiency to prevent the entry of radioactive particles (fallout) by the installation of special filters. The designs of the air conditioning system have done according to the measurements of global standards. Therefore, there is good ventilation inside these facilities.

Ventilation system consists of the following devices:

- Existing devices: Air supply vents, air supply pipes, air pull fans, fresh air pipes, exhaust air pipes and exhaust air vents;

- Devices should be provided: Storm resistant valves, suitable filters, high pressure scale, decrease pressure valves and toxic gases blockers. Pipes should be suspended in the ceiling slab by springs; 
- Air filtration system: This system should be provided to the ventilation system of the stations and tunnels to give protection against the effects of weapons (fallout and poisonous gases). It includes primary filters, suspended matters filters, toxic gases filters and lime stone filters.

(2) Food

Food need to be provided in sufficient amounts to the hidden people as each one needs 1,500-2,000 calories per day.

(3) Water

There are water supplies in all of these underground stations and tunnels. Water should be reserved in standby reservoirs for drinking and other usages. At least 10 liters for each person per day for 14 days after the attack should be provided. Water reservoirs should be made of concrete, iron or plastic and exist inside the stations to protect them from the explosions.

(4) Sanitation (toilets and sewage) [18]

All of these underground stations and tunnels have sanitation systems (basins, toilets and urinals). Dry lavatories, showers and toilets in the decontamination rooms should be provided. The tunnels have been provided with two stations to divert water. The rain water that may seep through the entrances and exits of the stations, as well as sewage from passenger stations are being driven out by two water stations with a capacity of $175 \mathrm{~m}^{3} /$ hour [14]. The surface water that might seep into these facilities is collected and expelled to the outside by dewatering pumps.

(5) Lighting

All Underground Metro stations are equipped with sufficient lighting to provide the security for citizens. The adapters provide lighting for the stations of the three metro lines, for the tunnels, the equipment and devices. These underground stations and tunnels are provided with florescent bulbs giving comfortable lighting range from 100-300 lux. They have a system of lightings used in emergencies, especially in vital sites, with separate batteries and special keys.
(6) Electricity needs [19]

The tunnels have been provided with a transformer station 220 kilo volt to provide the three lines with needed power. There are also four stations to strengthen electricity distributed along the tunnel to supply the necessary electricity. There is also a back-up adapter for each power station operates automatically in case of power failure. The batteries can be used in extreme emergency cases enough for two hours. The stations and tunnels are provided with electricity and electrical generators to work when power failure. They have internal radio to assist citizens in emergency situations. It is preferable fixing a spare electric generator in a safe room inside the station works by diesel that can be stored inside a reservoir close to the electric generator. Also, they are provided with automatic control system and ground system.

The underground stations and tunnels also have electricity key plates, and a safety system against thunderbolts and fire, as it automatically cuts off electricity. There are also fire alarm systems, consist of sensors for heat or smoke, distributed in different places inside stations and tunnels, responsible for giving signs to the officials to avoid fire. There are also internal telephone lines and external telephone lines for calling the civil defense forces in case of emergencies. It would preferable fixing communication systems for giving instructions to the hidden people, also providing wireless communication systems for calling officials-a system for receiving radio and television transmission. Spare parts should be provided and stored in special rooms.

(7) Medical services

All of these Underground Metro stations have first aid kits and quarantine. They should be provided with essential drugs, appliances, instruments and medical books. Any one of the publications from the Bureau of Health Education of the American Medical Association would be helpful when a physician is not available. 
(8) Oxygen cylinders

In first aid room, there should be provided oxygen cylinders for being used in treating people who suffer the rise of $\mathrm{CO}_{2}$ rate in air.

(9) Safety valves against pressure

These valves would mitigate the pressure resulting from the explosion inside stations and tunnels. Storm resistant valves should be provided in the ventilation systems. Air vents should be equipped with storm resistant valves. These valves must resist negative and positive pressure until 10 atmosphere (reflected pressure). The additional pressure in the stations and tunnels should be in the range from 50-250 pascal. Permitted internal pressure should not be less than 100 pascal for any space.

(10) Color and aesthetics

The entrances and exits of stations have beautiful graphics [14]. Their floors and walls are cladded with granite. Interior paints are oil. Underground stations have beautiful colors. The tunnels should be painted with nice colors, which would have a positive effect on the psychological state of the hidden people. Stations have seats and suitable materials in paving platforms to prevent slipping, in addition to, taking into account the aesthetics of the materials used in lining the walls and ceilings. The tunnels have iron bars on their floors. Therefore, they should be covered with light plastic plates when converting the tunnels to public shelters. These plates can be assembled and stored in rooms when re-use of tunnels for the passage of trains.

(11) Sound/noise

Sound is calm inside underground stations and tunnels (less than 40 Decibel) which provide a comfortable atmosphere for the hidden people.

(12) System of protection against electromagnetic pulses [20]

This system does not exist in the stations. Therefore, it should be provided to protect the electrical equipment from electromagnetic waves that could hinder their working or causing their burning.
(13) System of protection against fire

There is a system of protection against fire in the stations and tunnels. Also, there are enough fire extinguishers in all parts of the stations. All Underground Metro stations are equipped with an integrated system for firefighting works automatically. The smoking is forbidden inside the stations [16]. Electrical machinery and generator rooms are well insulated from the rest of the station parts by walls and fire-resistant doors. They are equipped with automatic fire extinguishing system.

\subsection{Spaces Need to be Assigned Inside Underground Cairo Metro Stations and Tunnels Used as Nuclear Shelters}

The station will be divided into various spaces, these spaces will be [6]:

(1) Entrances

All stations have stairs, elevators and multiple ways to guide citizens to the entrances and exits. Also, they have guides on the entrances and exits to guide people to the right direction. At the entrance of each station there is an illuminated panel by underground sign. There is a map of the streets within each station. They have sufficient numbers of entrances and exits to avoid contention of citizens. All the stations have been provided with automatic control devices to allow the entry of passengers only. Entrances of stations are wide to facilitate the entering of hidden people. The stations have separation of entrances and exits so that citizens can get out at emergency cases, within a period of not more than a minute.

The two ends of the tunnel should be provided with two reinforced massive bridges to close the two slots. These bridges have entrance doors for citizens. These bridges will automatically move. There are rooms to control everything in the shelter. All current doors of the stations located on the ground surface should be changed with lead armored doors open in both directions to resist blast and fragments resulting from 
the bomb and protect the hidden people from gamma radiations emanating from fallout

(2) Emergency outlets

Some of the stations entrances may be used as outlets in emergencies to ease the coming out of the hidden people. Stations have underground passes to move from the platform to another. There is a pedestrian sidewalk adjacent to the wall of the tunnel from inside runs between the stations [15].

(3) Controlled room

It should be provided after each entrance. It contains two resistance doors (against pressure, blast, gases and fallout radiations). The two doors do not open at the same time.

(4) Decontamination room

It should be provided after each controlled room. Its main goal is to make the shelter safe from any contamination. It should contain dressing room, store room for contaminated clothes of hidden people, basins, showers and toilets.

(5) Spaces for living, sleeping and eating meals

Stations floors can be covered with plastic mats to be used for sitting, sleeping, eating; these mats can easily be stored when reusing the stations in peaceful times [21].

(6) A space for storing water, food, bed rolls and clothes

(7) A space for preparing food

(8) Spaces for medical services, first aids, and quarantine

(9) Space for officers supervising the process of hiding inside the garage

(10) A space for equipment and the electricity generator

(11) A space for Dry lavatories

(12) A space for recreational means to entertain the hidden people

The entrance passage of the nuclear shelter should be provided with a door and stairs leading to the decontamination space where there are a basin and a toilet. This space leads then to the main space of the shelter which may be divided into the living space, the sleeping space, the cooking space, storing space, eating space and equipment space. This main space leads to an escape passage.

4.5 Calculations of the Number of Hidden Persons Inside Underground Cairo Metro Stations and Tunnels When Used as Nuclear Shelters

\subsubsection{The First Underground Cairo Metro Line}

Average net area of the station (one floor) $=4,000$ $\mathrm{m}^{2}$ (Al Shohdaa, Orabi, Abd El Nasser, Sadat and Saad Zaghloul).

Net area of these stations $=4,000 \times 5=20,000 \mathrm{~m}^{2}$.

Net area of the tunnel of the first underground Cairo Metro line $=$ length $\times$ width $=5,961 \times 8.7=51,861 \mathrm{~m}^{2}$.

Net area of all stations and tunnels of the first underground Cairo Metro line $=20,000+51,861=$ $71,861 \mathrm{~m}^{2}$.

According to the international standards, the net area required for a hidden person $=2 \mathrm{~m}^{2}$.

All stations and tunnels of the first underground Cairo Metro line can accommodate $=71,861 / 2=$ 35,930 persons.

\subsubsection{The Second Underground Cairo Metro Line}

Average net area of the station (one floor) $=3,585$ $\mathrm{m}^{2}$ (Al Shohdaa and Sadat stations).

Net area of these stations $=3,585 \times 2=7,170 \mathrm{~m}^{2}$.

Net area of the station (two floors) $=7,170 \mathrm{~m}^{2}$ (Mazallat station).

Net area of the station (three floors) $=10,755 \mathrm{~m}^{2}$, (Khalafawy, Saint Teresa, Road El Farag, Massara, El Attaba, Mohamed Najuib, Opera, Dokki and Research stations).

Net area of these stations $=10,755 \times 9=96,795 \mathrm{~m}^{2}$.

Net area of all stations of the second underground Cairo Metro line $=111,135 \mathrm{~m}^{2}$.

Net area of the tunnel of the second underground Cairo Metro line $=$ length $\times$ width $=13,000 \times 8.35=$ $108,550 \mathrm{~m}^{2}$.

Net area of all stations and tunnels of the second underground Cairo Metro line $=111,135+108,550=$ 
$219,685 \mathrm{~m}^{2}$.

All stations and tunnels of the second underground Cairo Metro line can accommodate $=219,685 / 2=$ 109,842 persons.

\subsubsection{The Third Underground Cairo Metro Line}

Net area of all stations (three floors) $=3,580 \times 3 \times$ $5+3,513 \times 3+3,580 \times 3+3,344 \times 3+3,315 \times 3=$ 91,956 $\mathrm{m}^{2}$ (Attaba, Bab El-Shaaria, El Geish, Abdou Pasha, Abbasia, Fair Zone, Stadium, Kolyet EL-Banat and $\mathrm{Al}$ Ahram stations).

Net area of the tunnel of the third underground Cairo Metro line $=$ length $\times$ width $=12,000 \times 8.35=$ $100,200 \mathrm{~m}^{2}$.

Net area of all stations and tunnels of the second underground Cairo Metro line $=91,956+100,200=$ $192,156 \mathrm{~m}^{2}$.

All stations and tunnels of the third underground Cairo Metro line can accommodate $=192,156 / 2=$ 96,078 persons.

Underground Cairo Metro lines, when used as public nuclear shelters, can accommodate $=35,930+109,842$ $+96,078=241,850$ persons.

\subsection{A Case Study of the Underground Road El-Farag} Metro Station (Line 2)

Station is located below the surface of Shobra street, between Saint Teresa station and Masara station. It consists of three underground floors (Fig. 9). One floor area $=3,585 \mathrm{~m}^{2}$ [22]. Net area of the station (three floors) $=3,585 \times 3=10,755 \mathrm{~m}^{2}$. The station can accommodate in emergencies $=10,755 / 2=5,377$ persons. The station has three entrances on the eastern side of Shobra street, as well as, three entrances on the western side of the same street. All entrances connect the surface of the street with tickets hall. There is an elevator for the disabled.

The height of the first floor (from the level of the tickets hall to the ground level) is $5.35 \mathrm{~m}$. The first floor contains tickets hall, station manager, police office, 2 staircases and 4 escalators that lead to the level of the second floor (technical rooms operation) (Table
1). The first floor contains 2 elevators for the disabled (elevator for each direction). The first floor contains 2 ventilation stations for first and second floors [22]. The height of the second floor is $4.5 \mathrm{~m}$ and is located at a depth of $9.85 \mathrm{~m}$ from the ground surface. This floor contains all technical operation rooms, training rooms, lectures and toilets. Also, it contains 8 staircases and 8 escalators connect this floor with the third level (platforms) [22].

The height of the third floor is $6.95 \mathrm{~m}$ and is located at a depth of $16.80 \mathrm{~m}$ below the ground surface. This floor contains platforms (3.50-7.50 m width) with chairs for passengers are made of fiberglass. This floor has ceramic walls and plastic paintings. The walls are decorated with mural paintings. Platforms have been made of Aswan granite. The platforms are equipped with firefighting boxes and cut off power supply in emergency situations. This floor has 8 staircases and 8 escalators connecting the platforms with the street level. It contains 2 elevators for the disabled (elevator for each direction) [22]. The air conditioners keep the temperature at $28{ }^{\circ} \mathrm{C}$ and the relative humidity at $60 \%$ inside the station. All mechanical equipment should be installed on inhibitors to protect them from vibration. This paper explains how to use this station as a public nuclear shelter (Fig. 10). In emergency situations, the tunnel and the third floor of the station can be used as sheltering space (Table 2). The citizens will use staircases, elevators and escalators to reach the third floor $(-3)$. The second floor $(-2)$ contains the mechanical and electrical equipment. The first floor (-1) contains the indirect spaces.

\section{The Selected underground Cairo Metro Stations}

Three underground Cairo Metro stations have been selected and a field study has been conducted to their floors to determine the usages of these floors; in addition to identify the planning, general and design features for each one of them; and to determine whether they can be used as protective structures for 


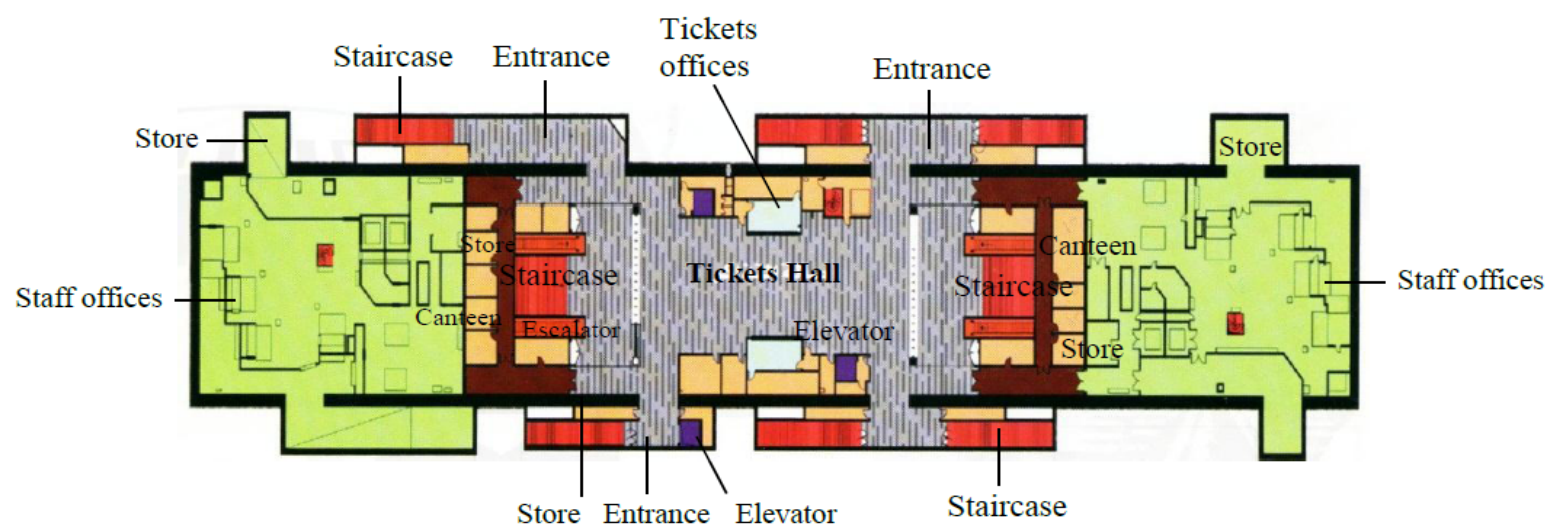

(a)

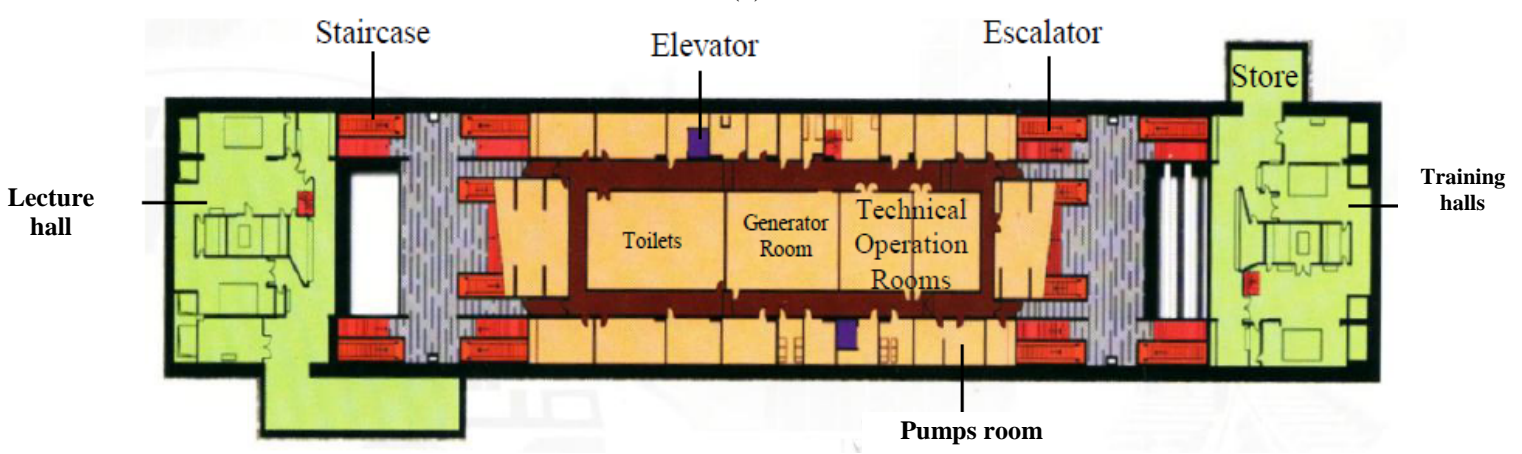

(b)

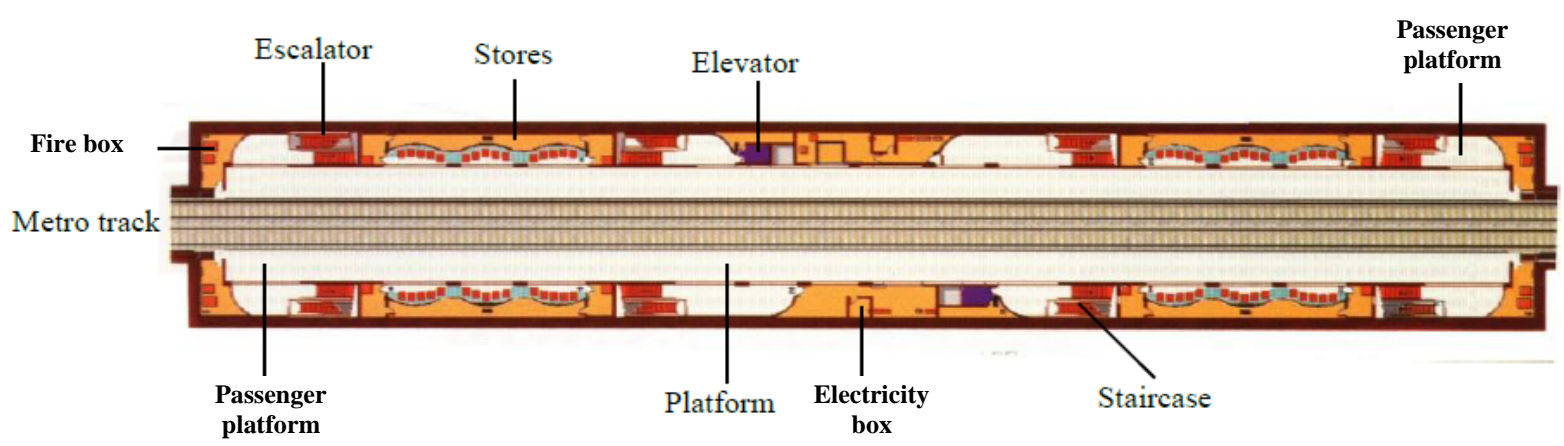

(c)

Fig. 9 The peaceful use of the underground road El-Farag Metro station, (a) basement floor (-1), (b) basement floor (-2) and (c) basement floor $(-3)[22]$.

Table 1 The peaceful use and the emergency use of all basements of the underground road El-Farag Metro station [22].

\begin{tabular}{|c|c|c|}
\hline Floor & The peaceful use & The emergency use \\
\hline Basement (-1) & $\begin{array}{l}\text { Entrances ( } 6 \text { staircases, } 2 \text { elevators for } \\
\text { disabled), tickets hall, tickets offices, } 28 \text { tickets } \\
\text { gates, } 2 \text { staircases and } 4 \text { escalators }\end{array}$ & $\begin{array}{l}\text { Entrances and exits, staff management room, controlled rooms, } \\
\text { decontamination rooms, } \\
\text { changing room, isolation room, first aid room, quarantine room, } \\
\text { kitchen and stores, food store, cleaning tools store, waste store, } \\
\text { corridors and staircases }\end{array}$ \\
\hline Basement (-2) & $\begin{array}{l}\text { Mechanical and electrical services (all } \\
\text { technical operation rooms), training halls, } \\
\text { lectures halls, toilets, } 8 \text { staircases, } 8 \text { escalators }\end{array}$ & $\begin{array}{l}\text { Technical operation rooms, ventilation and air-conditioning rooms, } \\
\text { filters room, electric generator room, pumps room, fuel tank room, } \\
\text { dry toilets, toilets, water tanks, waste store, corridor and staircases }\end{array}$ \\
\hline Basement (-3) & $\begin{array}{l}\text { Passenger, platforms, chairs and firefighting } \\
\text { boxes }\end{array}$ & $\begin{array}{l}\text { Sheltering space, toilets, dry toilets waste stores, stores, fire boxes, } \\
\text { electricity boxes and staircases }\end{array}$ \\
\hline Tunnels & Movement of trains & Sheltering space \\
\hline
\end{tabular}


The Use of Underground Metro Stations and Tunnels as Protective Structures in Case of Nuclear Emergencies

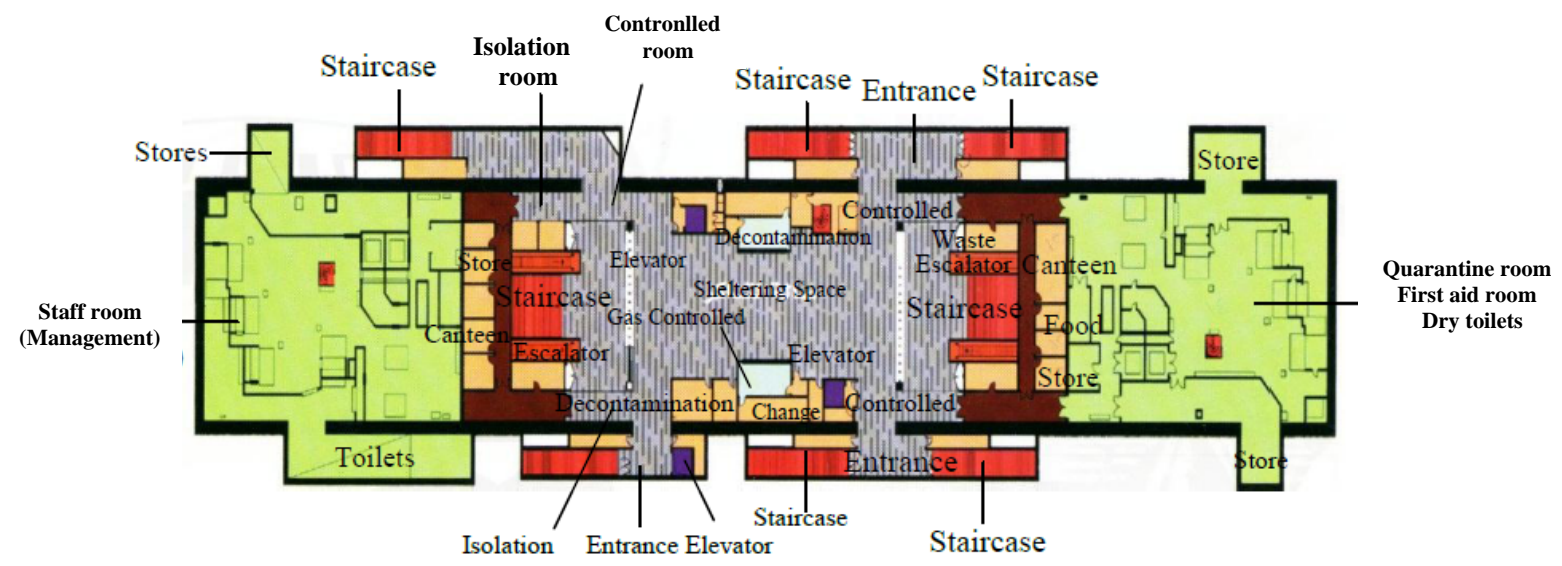

(a)

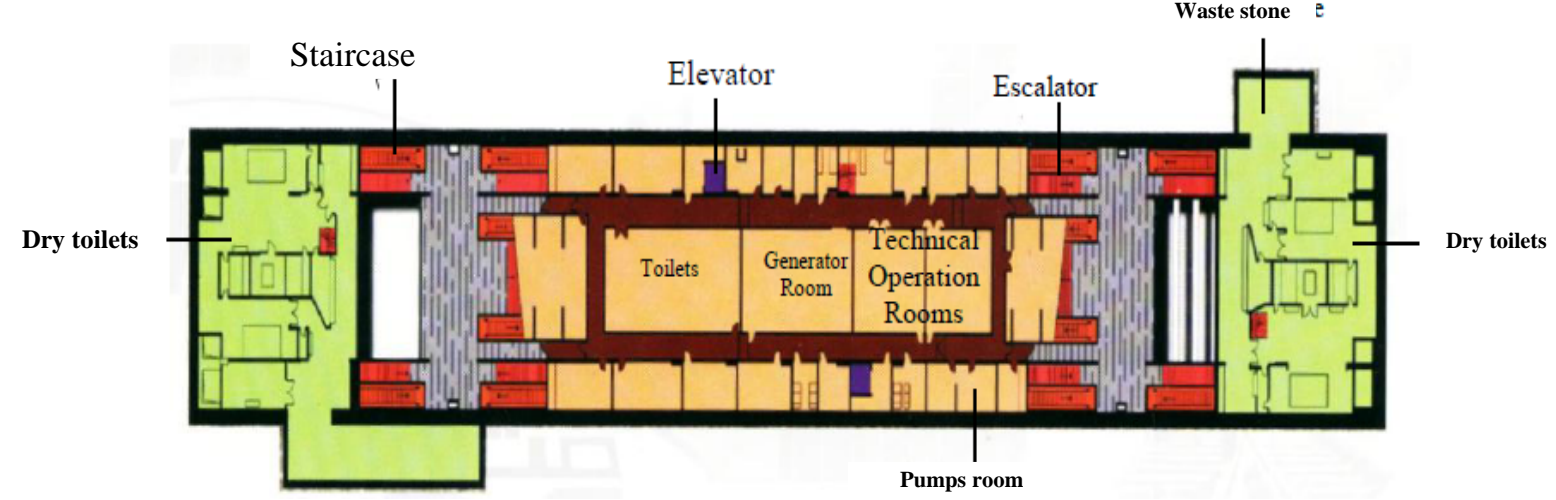

(b)

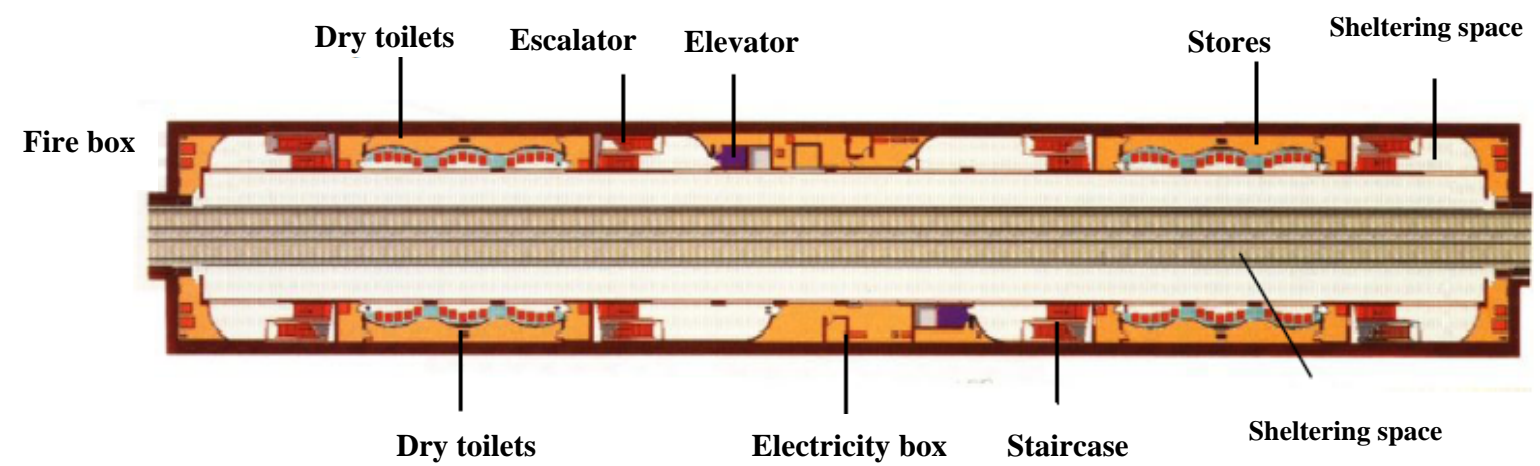

(c)

Fig. 10 The emergency use of the underground road El-Farag Metro station as a public nuclear shelter, (a) basement floor (-1), (b) basement floor (-2) and (c) basement floor (-3).

Table 2 Existing spaces and needed spaces of the underground road El-Farag Metro station to dual use as public nuclear shelter [22].

\begin{tabular}{ll}
\hline Existing spaces & Needed spaces to use the station as N.S. \\
\hline Entrances and exits & Controlled rooms \\
Sheltering spaces & Decontamination rooms \\
Toilets & Dry toilets \\
Management room & Toilets \\
Ventilation and air-conditioning rooms & Electric generator room \\
Air room & Fuel tank room \\
\hline
\end{tabular}


citizens in emergencies. These underground Metro Stations are Abd El Nasser Station (Line 1) (Fig. 11 and 12), Road El-Farag Station (Line 2) (Fig. 9) and Stadium Station (Line 3) (Figs. 13 and 14). The following is the results of this field study.

\section{Planning, General and Design Features of} the Selected Underground Cairo Metro Stations

Table 3 shows the planning features of the selected underground Cairo Metro stations. Table 4 shows the general features of the selected underground stations. Table 5 shows the design features of the selected underground stations.

7. Calculation of Protective Factors of the Three Selected Underground Cairo Metro Stations Which Can be Used as Nuclear Shelters in Emergency

The protection afforded by a building against the

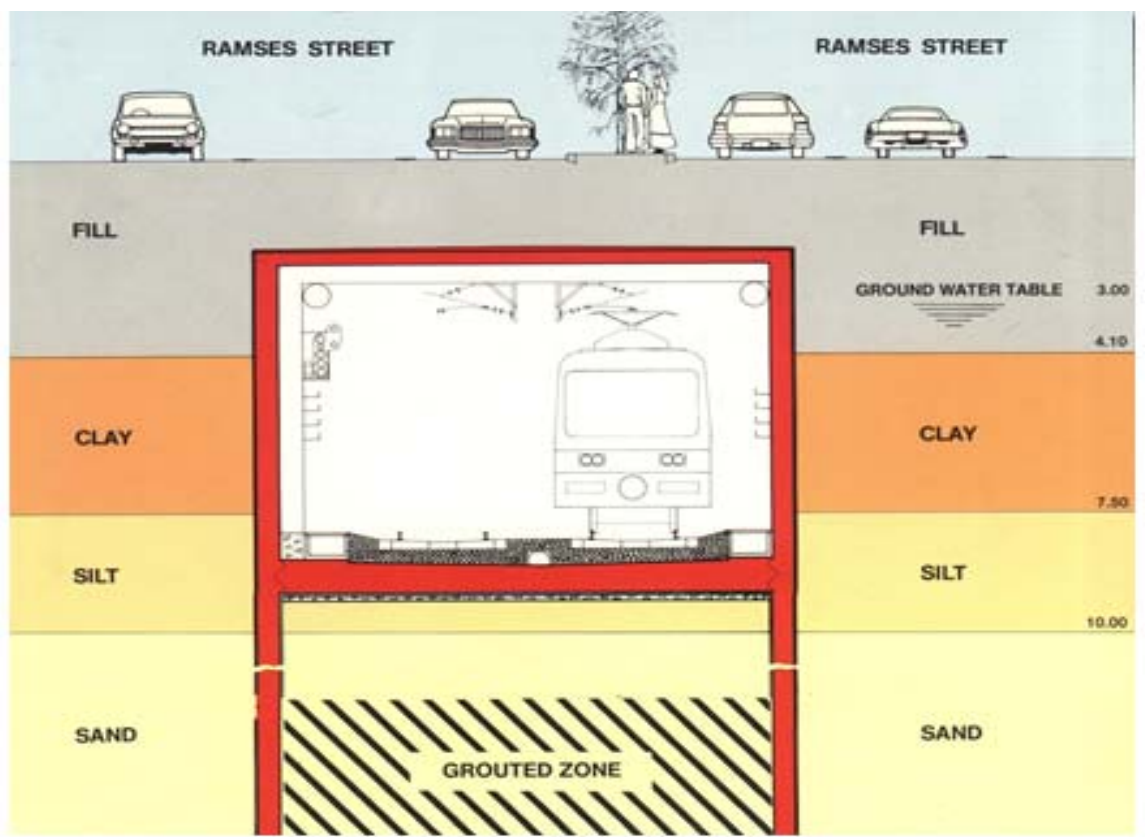

Fig. 11 Cross-Section of the First Tunnel [12].

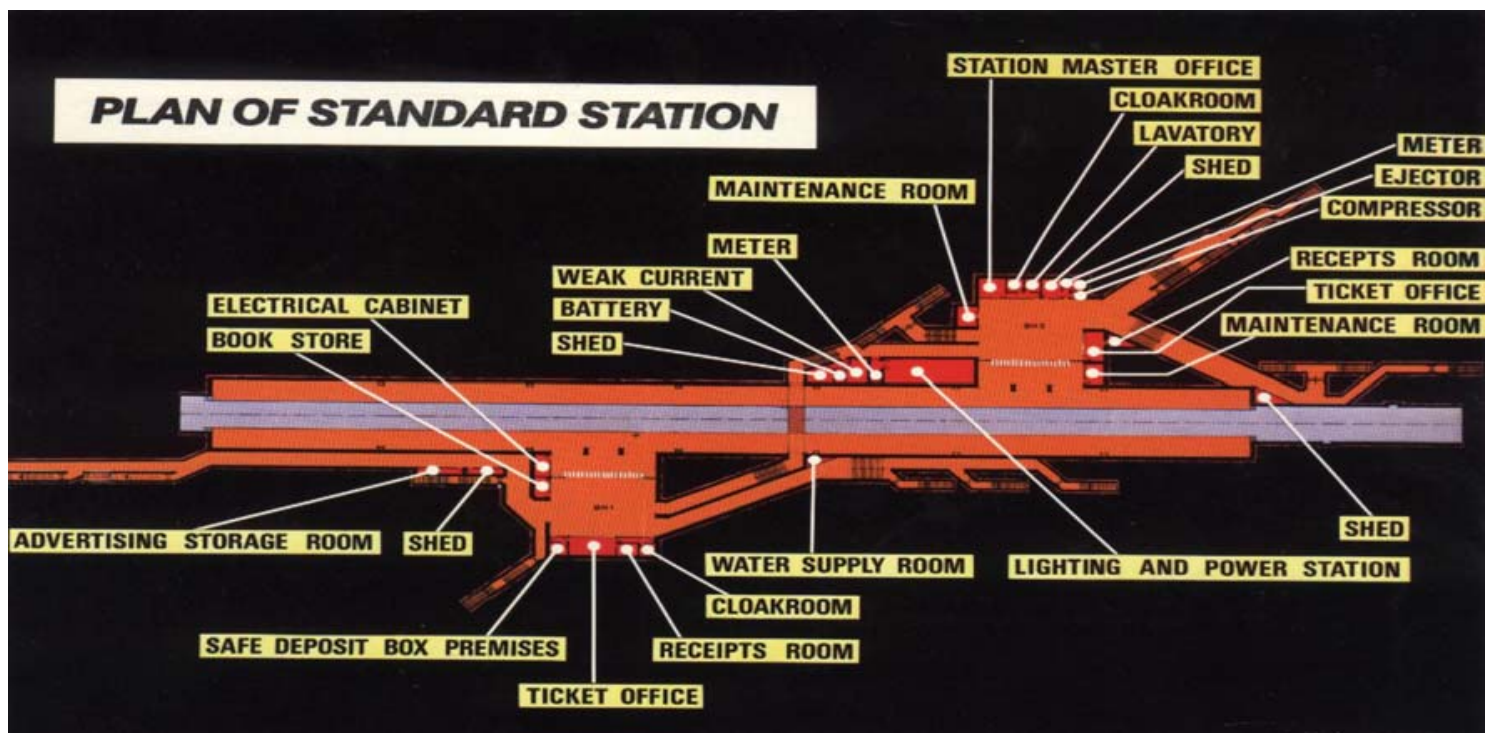

Fig. 12 Plan of Abd El Nasser station [12] 


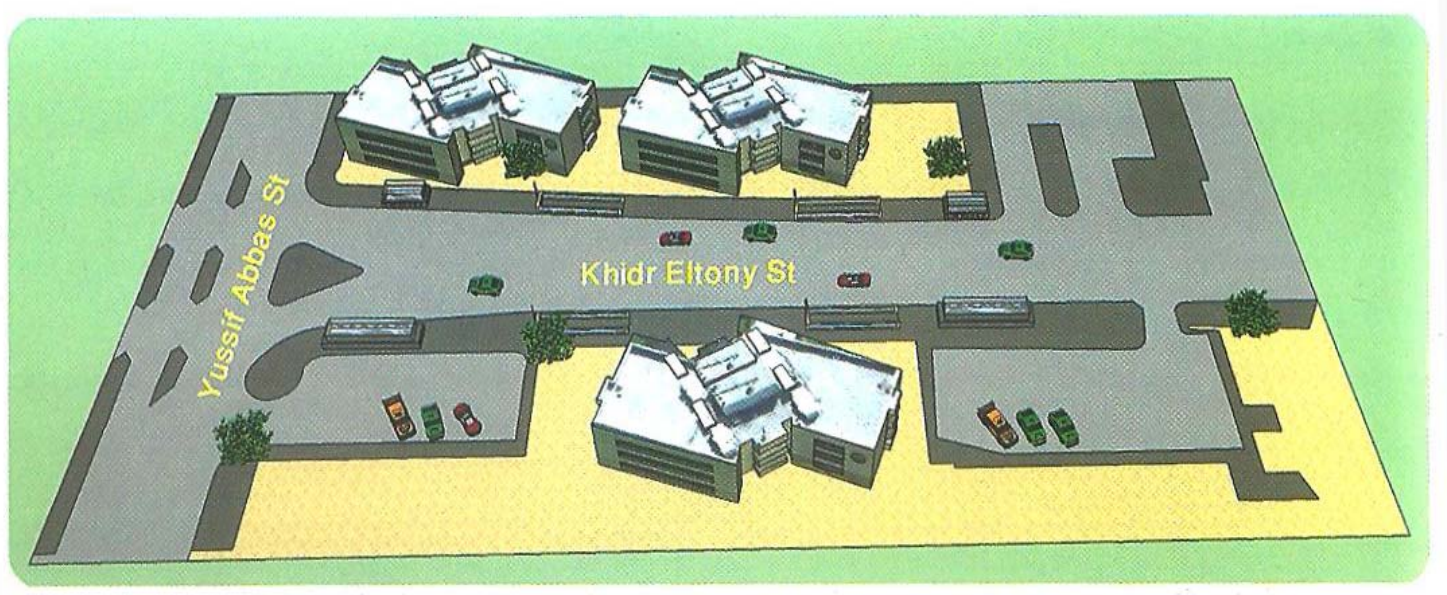

Fig. 13 Perspective of Stadium Station [11].

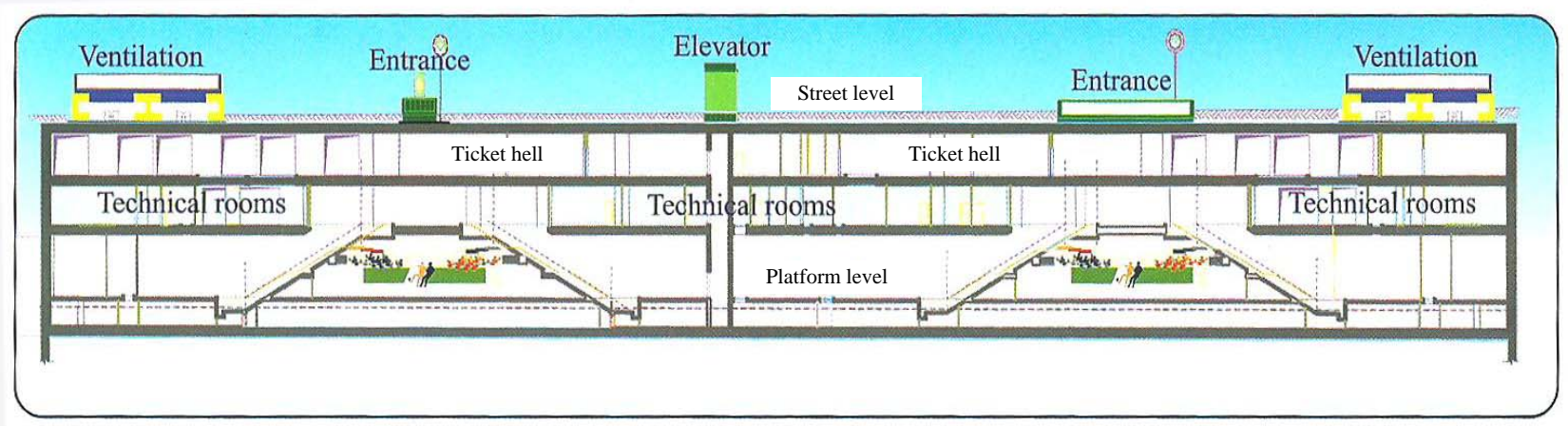

Fig. 14 Longitudinal-section of Stadium Station [11].

gamma radiation from fallout is expressed as the Protective Factor (PF) of the building. It is the factor by which the dose-rate received by a person inside the building is reduced as compared with that received by a person standing in the open on flat ground. Thus, if a building has a PF of 100, it means that the dose-rate inside the building is $1 / 100$ of the dose-rate outside [20]. The site of shelter inside a building determines its ability of providing safety against gamma radiation from fallout resulting from nuclear explosion. It determines the protective factor degree of a shelter [20].

Radiation from fallout enters the building from five plane sectors. One is on the roof and four are on the ground. Each of the five sectors is regarded as providing a separate contribution to the radiation intensity inside the building and each contribution is calculated as a percentage of the total intensity outside. The contributions are then summed to give the total percentage of the total intensity outside. The contributions are then summed to give the total percentage intensity inside and the reciprocal of this fraction is the protective factor. It is easier to use a standard proforma [20].

This method has been used to calculate the Protective Factors (PF) at basement (-1), basement $(-2)$, and basement (-3) of the three selected underground stations. It is sufficient to mention the results of the protective factors calculations of the three selected underground stations which can be used as nuclear shelters in emergency. Tables 6 and 7 show comparisons of these results. 
Table 3 Planning features of the selected underground Cairo Metro stations.

\begin{tabular}{|c|c|c|c|c|c|c|}
\hline No. & Subject & Details & $\begin{array}{l}\text { First underground } \\
\text { Cairo Metro line } \\
\text { (Abd El Nasser } \\
\text { station) } \\
\end{array}$ & $\begin{array}{l}\text { Second underground } \\
\text { Cairo Metro line } \\
\text { (Road El-Farag } \\
\text { station) } \\
\end{array}$ & $\begin{array}{l}\text { Third underground } \\
\text { Cairo Metro line } \\
\text { (Stadium station) }\end{array}$ & Rate \\
\hline \multirow{2}{*}{1} & \multirow{2}{*}{ Current use of the station } & Used & $\sqrt{ }$ & $\sqrt{ }$ & $\sqrt{ }$ & $100 \%$ \\
\hline & & Unused & & & & $0 \%$ \\
\hline \multirow{2}{*}{2} & \multirow{2}{*}{ Users of the station } & Limited & & & & $0 \%$ \\
\hline & & Unlimited & $\sqrt{ }$ & $\sqrt{ }$ & $\sqrt{ }$ & $100 \%$ \\
\hline \multirow{2}{*}{3} & \multirow{2}{*}{ Usage of the station } & For riding and shops & $\sqrt{ }$ & $\sqrt{ }$ & & $67 \%$ \\
\hline & & For riding only & & & $\sqrt{ }$ & $33 \%$ \\
\hline \multirow{3}{*}{4} & \multirow{3}{*}{ Height of the station } & High & $\sqrt{ }$ & & & $33 \%$ \\
\hline & & Medium & & $\sqrt{ }$ & $\sqrt{ }$ & $67 \%$ \\
\hline & & Low & & & & $0 \%$ \\
\hline \multirow{2}{*}{5} & \multirow{2}{*}{$\begin{array}{l}\text { location of the platform } \\
\text { inside the station }\end{array}$} & Under the whole station & $\sqrt{ }$ & $\sqrt{ }$ & $\sqrt{ }$ & $100 \%$ \\
\hline & & Partially under & & & & $0 \%$ \\
\hline \multirow{2}{*}{6} & \multirow{2}{*}{$\begin{array}{l}\text { Ceiling level in } \\
\text { comparison to ground level }\end{array}$} & Ceiling above land surface & & & & $0 \%$ \\
\hline & & Ceiling under land surface & $\sqrt{ }$ & $\sqrt{ }$ & $\sqrt{ }$ & $100 \%$ \\
\hline \multirow[t]{2}{*}{7} & \multirow[t]{2}{*}{ Platform entrances } & $\begin{array}{l}\text { From inside and outside the } \\
\text { station }\end{array}$ & & & & $0 \%$ \\
\hline & & From inside the station only & $\sqrt{ }$ & $\sqrt{ }$ & $\sqrt{ }$ & $100 \%$ \\
\hline \multirow{2}{*}{8} & \multirow{2}{*}{$\begin{array}{l}\text { Access to the platform } \\
\text { "from inside the station" }\end{array}$} & By using stairs & & & & $0 \%$ \\
\hline & & Using stairs and lift & $\sqrt{ }$ & $\sqrt{ }$ & $\sqrt{ }$ & $100 \%$ \\
\hline \multirow{2}{*}{9} & \multirow{2}{*}{$\begin{array}{l}\text { Access to the station } \\
\text { "for people" }\end{array}$} & Fast and easily & $\sqrt{ }$ & $\sqrt{ }$ & $\sqrt{ }$ & $100 \%$ \\
\hline & & Hardly and taking a lot of time & & & & $0 \%$ \\
\hline \multirow{5}{*}{10} & \multirow{5}{*}{$\begin{array}{l}\text { Site of the station in } \\
\text { relation to the other } \\
\text { buildings }\end{array}$} & $\begin{array}{l}\text { Surround by buildings from all } \\
\text { the } 4 \text { sides }\end{array}$ & $\sqrt{ }$ & $\sqrt{ }$ & $\sqrt{ }$ & $100 \%$ \\
\hline & & From 3 sides only & & & & $0 \%$ \\
\hline & & From 2 sides only & & & & $0 \%$ \\
\hline & & From 1 side only & & & & $0 \%$ \\
\hline & & Away from the other buildings & & & & $0 \%$ \\
\hline \multirow{2}{*}{11} & \multirow{2}{*}{$\begin{array}{l}\text { Access to the station for } \\
\text { people in the streets }\end{array}$} & Direct and easy & $\sqrt{ }$ & $\sqrt{ }$ & $\sqrt{ }$ & $100 \%$ \\
\hline & & Complicated and difficult & & & & $0 \%$ \\
\hline \multirow{2}{*}{12} & \multirow{2}{*}{$\begin{array}{l}\text { Guiding signs lead to the } \\
\text { station }\end{array}$} & There are some & $\sqrt{ }$ & $\sqrt{ }$ & $\sqrt{ }$ & $100 \%$ \\
\hline & & There are not any & & & & $0 \%$ \\
\hline \multirow{4}{*}{13} & \multirow{4}{*}{ Cleanliness of the station } & No offensive smells & $\sqrt{ }$ & $\sqrt{ }$ & $\sqrt{ }$ & $100 \%$ \\
\hline & & Offensive smells & & & & $0 \%$ \\
\hline & & Leakage & & & & $0 \%$ \\
\hline & & Rubbles and debris & & & & $0 \%$ \\
\hline
\end{tabular}

Table 4 General features of the selected underground Cairo Metro stations.

\begin{tabular}{lll}
\hline Name of the station & Station area $\left(\mathrm{m}^{2}\right)$ & $\begin{array}{l}\text { Capacity “number” of hidden people it can } \\
\text { accommodate in emergencies }\end{array}$ \\
$\begin{array}{l}\text { First underground Cairo Metro line } \\
\text { (Abd El Nasser station) }\end{array}$ & 4,000 & 1,790 \\
$\begin{array}{l}\text { Second underground Cairo Metro line } \\
\text { (Road El-Farag station) }\end{array}$ & 10,755 & 1,790 \\
$\begin{array}{l}\text { Third underground Cairo Metro line } \\
\text { (Stadium station) }\end{array}$ & 10,740 & 5,370 \\
\hline
\end{tabular}


The Use of Underground Metro Stations and Tunnels as Protective Structures in Case of Nuclear Emergencies

Table 5 Design features of the selected underground Cairo Metro stations.

\begin{tabular}{|c|c|c|c|c|c|c|c|}
\hline \multicolumn{3}{|c|}{ No. Subject } & Details & $\begin{array}{l}\text { First underground } \\
\text { Cairo Metro line } \\
\text { (Abd El Nasser } \\
\text { station) }\end{array}$ & $\begin{array}{l}\text { Second underground } \\
\text { Cairo Metro line } \\
\text { (Road El-Farag } \\
\text { station) }\end{array}$ & $\begin{array}{l}\text { Third underground } \\
\text { Cairo Metro line } \\
\text { (Stadium station) }\end{array}$ & Rate \\
\hline \multirow{2}{*}{1} & \multirow{2}{*}{\multicolumn{2}{|c|}{ Number of station stories }} & 1 story & $\sqrt{ }$ & & & $33 \%$ \\
\hline & & & More than one & & $\sqrt{ }$ & $\sqrt{ }$ & $67 \%$ \\
\hline \multirow{2}{*}{2} & \multirow{2}{*}{\multicolumn{2}{|c|}{ Plan of the station }} & Simple & $\sqrt{ }$ & $\sqrt{ }$ & $\sqrt{ }$ & $100 \%$ \\
\hline & & & Complex & & & & $0 \%$ \\
\hline \multirow{3}{*}{3} & \multirow{3}{*}{\multicolumn{2}{|c|}{$\begin{array}{l}\text { Number of entrances to } \\
\text { the station }\end{array}$}} & 1 & & & & $0 \%$ \\
\hline & & & 2 & & & & $0 \%$ \\
\hline & & & More than 2 & $\sqrt{ }$ & $\sqrt{ }$ & $\sqrt{ }$ & $100 \%$ \\
\hline \multirow{3}{*}{4} & \multirow{3}{*}{\multicolumn{2}{|c|}{$\begin{array}{l}\text { Number of emergency } \\
\text { outlets of the station }\end{array}$}} & 1 & & & & $0 \%$ \\
\hline & & & 2 or more than 2 & $\sqrt{ }$ & $\sqrt{ }$ & $\sqrt{ }$ & $100 \%$ \\
\hline & & & No one & & & & $0 \%$ \\
\hline \multirow{3}{*}{5} & \multirow{3}{*}{\multicolumn{2}{|c|}{$\begin{array}{l}\text { Basement door from the } \\
\text { direction of the main stair } \\
\text { of the station }\end{array}$}} & $\begin{array}{l}\text { Door made of } \\
\text { aluminum and glass }\end{array}$ & & & & $0 \%$ \\
\hline & & & Fire gate & $\sqrt{ }$ & $\sqrt{ }$ & $\sqrt{ }$ & $100 \%$ \\
\hline & & & No doors & & & & $0 \%$ \\
\hline \multirow{4}{*}{6} & \multirow{4}{*}{\multicolumn{2}{|c|}{ External doors }} & Aluminum door with glass & & & & $0 \%$ \\
\hline & & & Iron door with glass & & & & $0 \%$ \\
\hline & & & Massive iron door & & & & $0 \%$ \\
\hline & & & Safety iron door & $\sqrt{ }$ & $\sqrt{ }$ & $\sqrt{ }$ & $100 \%$ \\
\hline \multirow{5}{*}{7} & \multirow{5}{*}{\multicolumn{2}{|c|}{ Internal doors }} & Iron plated with lead & & & & $0 \%$ \\
\hline & & & Iron & $\sqrt{ }$ & $\sqrt{ }$ & $\sqrt{ }$ & $100 \%$ \\
\hline & & & Aluminum & & & & $0 \%$ \\
\hline & & & Wooden & & & & $0 \%$ \\
\hline & & & No internal doors & & & & $0 \%$ \\
\hline \multirow{3}{*}{8} & \multirow{3}{*}{\multicolumn{2}{|c|}{ External walls }} & Reinforced concrete & $\sqrt{ }$ & $\sqrt{ }$ & $\sqrt{ }$ & $100 \%$ \\
\hline & & & Brick of $12 \mathrm{~cm}$ & & & & $0 \%$ \\
\hline & & & Brick of $25 \mathrm{~cm}$ & & & & $0 \%$ \\
\hline \multirow{14}{*}{9} & \multirow{14}{*}{ Finishing } & \multirow{6}{*}{ Walls } & Tiles & & & & $0 \%$ \\
\hline & & & Painting & $\sqrt{ }$ & $\sqrt{ }$ & $\sqrt{ }$ & $100 \%$ \\
\hline & & & Ceramics & & & & $0 \%$ \\
\hline & & & Plaster & & & & $0 \%$ \\
\hline & & & Marble & & & & $0 \%$ \\
\hline & & & No & & & & $0 \%$ \\
\hline & & \multirow{3}{*}{ Ceiling } & Painting & $\sqrt{ }$ & $\sqrt{ }$ & $\sqrt{ }$ & $100 \%$ \\
\hline & & & Plaster & & & & $0 \%$ \\
\hline & & & No & & & & $0 \%$ \\
\hline & & \multirow{5}{*}{ Floors } & Tiles & & & & $0 \%$ \\
\hline & & & Ceramics & & & & $0 \%$ \\
\hline & & & asphalt & $\sqrt{ }$ & $\sqrt{ }$ & $\sqrt{ }$ & $100 \%$ \\
\hline & & & Marble & & & & $0 \%$ \\
\hline & & & No & & & & $0 \%$ \\
\hline \multirow{3}{*}{10} & \multirow{3}{*}{\multicolumn{3}{|c|}{$\begin{array}{ll} & \text { Through windows and entrances } \\
\text { Ventilation } & \text { air conditions }\end{array}$}} & & & & $0 \%$ \\
\hline & & & & $\sqrt{ }$ & $\sqrt{ }$ & $\sqrt{ }$ & $100 \%$ \\
\hline & & & & & & & $0 \%$ \\
\hline
\end{tabular}


Table 5 continued

\begin{tabular}{|c|c|c|c|c|c|c|}
\hline No. Subject & Details & & $\begin{array}{l}\text { First underground } \\
\text { Cairo Metro line } \\
\text { (Abd El Nasser } \\
\text { station) } \\
\end{array}$ & $\begin{array}{l}\text { Second underground } \\
\text { Cairo Metro line } \\
\text { (Road El-Farag } \\
\text { station) }\end{array}$ & $\begin{array}{l}\text { Third underground } \\
\text { Cairo Metro line } \\
\text { (Stadium station) }\end{array}$ & Rate \\
\hline \multirow{3}{*}{ Lightening } & \multicolumn{2}{|c|}{ Fixed in the ceiling } & $\sqrt{ }$ & $\sqrt{ }$ & $\sqrt{ }$ & $100 \%$ \\
\hline & \multicolumn{2}{|c|}{ Fixed in walls } & & & & $0 \%$ \\
\hline & \multicolumn{2}{|l|}{ No lightening } & & & & $0 \%$ \\
\hline \multirow{9}{*}{$\begin{array}{l}\text { Sanitation } \\
\text { services of } \\
\text { the station }\end{array}$} & \multirow{3}{*}{$\begin{array}{l}\text { Water } \\
\text { reservoir }\end{array}$} & Sufficient & $\sqrt{ }$ & $\sqrt{ }$ & $\sqrt{ }$ & $100 \%$ \\
\hline & & Insufficient & & & & $0 \%$ \\
\hline & & No reservoirs & & & & $0 \%$ \\
\hline & \multirow{2}{*}{ Toilets } & Some & $\sqrt{ }$ & $\sqrt{ }$ & $\sqrt{ }$ & $100 \%$ \\
\hline & & No Toilets & & & & $0 \%$ \\
\hline & \multirow{2}{*}{ Basins } & Some & $\sqrt{ }$ & $\sqrt{ }$ & $\sqrt{ }$ & $100 \%$ \\
\hline & & No basins & & & & $0 \%$ \\
\hline & \multirow{2}{*}{ Sanitation } & Exist & $\sqrt{ }$ & $\sqrt{ }$ & $\sqrt{ }$ & $100 \%$ \\
\hline & & No sanitation & & & & $0 \%$ \\
\hline \multirow{6}{*}{$\begin{array}{l}\text { Other } \\
\text { equipment }\end{array}$} & \multirow{2}{*}{$\begin{array}{l}\text { Fire } \\
\text { extinguisher }\end{array}$} & Exist & $\sqrt{ }$ & $\sqrt{ }$ & $\sqrt{ }$ & $100 \%$ \\
\hline & & Not exist & & & & $0 \%$ \\
\hline & \multirow{2}{*}{ Fire wheels } & Exist & $\sqrt{ }$ & $\sqrt{ }$ & $\sqrt{ }$ & $100 \%$ \\
\hline & & Not exist & & & & $0 \%$ \\
\hline & \multirow{2}{*}{ First aid kits } & Exist & $\sqrt{ }$ & $\sqrt{ }$ & $\sqrt{ }$ & $100 \%$ \\
\hline & & Not exist & & & & $0 \%$ \\
\hline
\end{tabular}

Table 6 A comparison of protective factors of the three selected underground Cairo Metro stations which can be used as nuclear shelters.

\begin{tabular}{llll}
\hline Garage's name & $\begin{array}{l}\text { Protective factor of } \\
\text { basement (-1) }\end{array}$ & $\begin{array}{l}\text { Protective factor of } \\
\text { basement (-2) }\end{array}$ & $\begin{array}{l}\text { Protective factor of } \\
\text { basement (-3) }\end{array}$ \\
\hline $\begin{array}{l}\text { First underground Cairo Metro line } \\
\text { (Abd El Nasser station) }\end{array}$ & 482 & ----- & ----- \\
$\begin{array}{l}\text { Second underground Cairo Metro line } \\
\text { (road El-Farag station) }\end{array}$ & 510 & 1,097 & 2,138 \\
$\begin{array}{l}\text { Third underground Cairo Metro line } \\
\text { (stadium station) }\end{array}$ & 536 & 1,142 & 2,278 \\
\hline
\end{tabular}

Table 7 A comparison of the capacity of the three selected underground Cairo Metro stations which can be used as nuclear shelters.

\begin{tabular}{llll}
\hline $\begin{array}{l}\text { No. of persons } \\
\text { accommodated in }\end{array}$ & $\begin{array}{l}\text { First underground } \\
\text { Cairo Metro line } \\
\text { (Abd El Nasser station) }\end{array}$ & $\begin{array}{l}\text { Second underground } \\
\text { Cairo Metro line } \\
\text { (road El-Farag station) }\end{array}$ & $\begin{array}{l}\text { Third underground } \\
\text { Cairo Metro line } \\
\text { (stadium station) }\end{array}$ \\
\hline Basement (-1) & 2,000 & 1,792 & 2,500 \\
Basement (-2) & ---- & 1,792 & 2,500 \\
Basement (-3) & ----- & 1,793 & 2,500 \\
Total no. & 2,000 & 5,377 & 7,500 \\
\hline
\end{tabular}




\section{Results and Conclusions}

Station (Line 3) proved to be larger in area than station (Line 2) which is larger in area than station (Line 1). Station (Line 3) contains areas with the highest PF values of the three selected underground stations as its basements are more protected by several overhead soil layers (largest in depth). Station (Line 2) contains areas with higher PF values than station (Line 1).

Most Underground Metro stations and tunnels are characterized by high protective factors, as they are totally located under the ground surface. Their structures are made of reinforced concrete with high thickness preventing gamma radiations emanating from fallout from penetrating into these Underground Metro stations and tunnels. Thus, they are qualified for dual-use as nuclear shelters.

The total area of the three underground Cairo Metro lines is 483,700 $\mathrm{m}^{2}$, which can accommodate 241,850 persons. It can be used as protective structures for the citizens of Cairo city against the dangerous effects of conventional or nuclear weapons.

The protective factor for any Underground Metro station can be improved by building a screen from blocks and by blocking its entrances by sand bags or any material of high density. Also, it can be improved by fixing gates plated with lead (or any material of high density) on its entrance and exit.

The intermediate spaces of the lower floors are of the highest levels of protective factors. The more the depth of the station or tunnel ground under land surface, the more the protective factor inside the station or tunnel will be.

The more the density and thickness of the Underground Metro station or tunnel's building materials, the more the protective factor inside the station or the tunnel will be. The reinforced concrete material has a high density, so that it prevents gamma radiations from fallout to infiltrate inside shelters and therefore, it is one of the factors that increase the protective factors inside shelters.

The Underground Metro stations and tunnels which their spaces are well-designed, situated in the best places inside the city, their structures are made of the best building materials (regarding to the density and thickness of these materials); all of these factors help in increasing the level of protective factor of these nuclear shelters.

The floors of the underground Cairo Metro stations and tunnels are well designed and structured as they have wide entrances facilitating the entrance of hidden people into the stations and tunnels. They also have wide spaces characterized by their high ceilings. People can reach so easily to these Underground Metro stations and tunnels either through staircases or elevators in few minutes. They are well isolated from any source of surface or ground water. They have moderate temperatures and are well lighted and ventilated by air conditioning systems, also they are not noisy. They are provided with firefighting systems, and have a number of fire extinguishers and internal telephone lines. They have water supplies and sanitation systems. So, they can be used as protective structures in case of nuclear emergencies.

\section{Recommendations}

This research recommends architects and structural engineers to design Underground Metro stations and tunnels with the concept of being protective structures in case of nuclear emergencies after providing them with the necessary requirements.

It is recommended to:

- Fix doors plated with lead to resist pressure and radiations on the entrances of Underground Metro stations, as well as adjust the doors to open from both sides, as this will ease the entrance of people who seek hiding;

- Fix filters for clarifying air from the penetrating particles of fallout, and of poisonous gases. In addition to, fix safety valves to ease pressure;

- Design some spaces left for different uses inside 
the Underground Metro stations used as protective structures;

- Store sufficient amounts of food for hidden people, and also sufficient amounts of water inside reservoirs;

- Provide Underground Metro stations with dry lavatories, hygienic system, oxygen cylinders and first aids kits;

- Fix lightening system used in emergencies, and a spare electric generator;

- Fix a number of external telephone lines, wireless lines to phone the civil defence in case of emergencies;

- Provide communication systems and a safety system against electromagnetic pulses inside Underground Metro stations and tunnels;

- Place directory signs leading to entrances of Underground Metro stations;

- Paint Underground Metro stations and tunnels with nice colors that will affect the psychological state of the hidden people.

Civil defense authority is recommended to conduct a field survey of all Underground Metro stations and tunnels to determine the stations and tunnels, which can be dual-used as protective structures to protect citizens and calculate the $\mathrm{PF}$, radiations attenuation and dose assessments in each one of them, and determine the number of people who can be protected by these Underground Metro stations and tunnels.

\section{References}

[1] Moore, M. 1980. "Building for the Bomb.” Building 36: 39-42.

[2] Ormerod, R. N. 1993. Nuclear Shelters: A Guide to Design. London: The Architectural Press Limited.

[3] Popkess, B. 2001. The Nuclear Survival Hand Book. Arrow Books Limited. USA: Collier Books.

[4] Phillips, B. 2004. "Take Shelter (Nuclear Survival Shelter for Domestic Use).” Building Design 493 (May): 24-25.

[5] Dumbleton, B. 2003. "London's Silent Shelter Tunnels."
New Civil Engineer 771: 14-15.

[6] Sisson, G. N. 1980. Underground for Nuclear Protection. USA: Pergamon Press Ltd..

[7] Gant, K. S., and Halland, C. M. 1979. "Community Shelters for Protection from Radioactive Fallout: Availability and Patterns of Probable Use.” Health Physics 37: 221-230.

[8] Dannish, S. A., and Golam, M. A. 1993. "Shelters against Explosions of Nuclear and Other Non-conventional Warfare.” International Journal for Housing 17 (3): 163-171.

[9] Chester, C. V., and Zimmerman, G. P. 1987. "Civil Defence Shelters: A State of the Art Assessment.” Tunneling Underground Space Technology 2 (4): 401-428.

[10] Ministry of Information, State Information Service. 1999. Underground Metro New Life Artery. Arab: State Information Service Press.

[11] Ministry of Transport. 2015. Projects, in the Occasion of Inauguration of Line 3 Phase 2 (Abbassia-Al Ahram). Cairo: Kornesh EL-Nile, AL-Ahram Press.

[12] Ministry of Transport. 1990. Greater Cairo Underground Metro. Cairo: Kornesh EL-Nile, AL-Ahram Press.

[13] Ministry of Transport. 1999. Greater Cairo Metro Basic Network. Cairo: Kornesh EL-Nile, AL-Ahram Press.

[14] Ministry of Information. 1999. The Underground: Another Hi-tech Show Case. Cairo: State Information Service Press.

[15] Ministry of Information. 1998. The Underground: A Project for the Future. Cairo: State Information Service Press.

[16] Arab Republic of Egypt. 2000. Achievements of the Transport \& Communications Sector: During the Period from 1981 till 1998. Cairo: Ministry of Transport and Communications.

[17] Kearny, C. H. 1987. Nuclear War Survival Skills. USA: Oregon Institute of Science and Medicine Cave Junction Oregon.

[18] Hanesalo, B. A., and Hanesalo, K. E. 1996. Advanced Protective Shelter Design. USA: Military, Info. Product.

[19] Hanesalo, B. A., and Hanesalo, K. E. 1997. Fallout Shelter Design Collection. USA: Military, Info. Product.

[20] Home Office. 1982. Domestic Nuclear Shelters, Technical Guidance. London: HMSO.

[21] Home Office. 1981. Protect and Survive. London: HMSO.

[22] Ministry of Transport. 1998. Second Underground Greater Cairo Metro Line: Road El-Farag Station. Cairo: Kornesh EL-Nile, AL-Ahram Press. 